\title{
Régimen de responsabilidad en el contrato de transporte de viajeros por carretera
}

Liability regime in the contract of carriage of passengers by road

\author{
BLANCA ROMERO MATUTE
}

Profesora Titular de Derecho Mercantil

Universidad de Cádiz (España)

blanca.romero@uca.es

https://orcid.org/0000-0003-1341-0335

\begin{abstract}
Resumen: El estudio tiene por objeto el análisis de la responsabilidad en el marco del contrato de transporte terrestre de viajeros por carretera. En particular, se estudia la responsabilidad del porteador, cuyo alcance viene determinado por distintos regímenes legales, que convergen en ocasiones de forma cumulativa y, en otras, de forma subsidiaria. Desde esta perspectiva se analizan también las distintas coberturas asegurativas que, bien con carácter obligatorio o voluntario, podemos encontrar en el ámbito del transporte de viajeros y la compatibilidad de las indemnizaciones a que pudieran dar lugar en caso de siniestro.
\end{abstract}

Abstract: The aim of this study is an analysis of liability within the framework of the contract of land carriage of passengers by road. In particular, the carrier' liability is studied, the extent of which is determined by different legal regimes, which converge sometimes cumulatively and sometimes in a subsidiary manner. From this perspective, the different insurance coverages, both mandatory and voluntary, that can be found in the field of passenger transport and the compatibility of the different compensations that could be claimed in the event of an accident, are also analysed.

Palabras claves: transporte, carretera, porteador, viajeros, responsabilidad, seguro obligatorio de viajeros, seguro de responsabilidad civil.

Cómo citar este trabajo: ROMERO MATUTE, Blanca, "Régimen de responsabilidad en el contrato de transporte de viajeros por carretera", Revista de Estudios Jurídicos y Criminológicos, n. ${ }^{\circ} 4$, Universidad de Cádiz, 2021, pp. 129-178, DOI: https://doi.org/10.25267/REJUCRIM.2021.i.4.06 
Keywords: transport, road, carrier, passengers, liability, compulsory passenger insurance, civil liability insurance.

Sumario: 1. CONSIDERACIONES CONCEPTUALES PREVIAS. 2. RÉGIMEN JURÍDICO Y MODALIDADES DE TRANSPORTE TERRESTRE POR CARRETERA. 3. CONTENIDO OBLIGACIONAL Y RÉGIMEN DE RESPONSABILIDAD EN EL TRANSPORTE DE VIAJEROS POR CARRETERA. 3.1 Obligaciones y responsabilidad del viajero. 3.2 Obligaciones y responsabilidad del porteador. 3.2.A. Las obligaciones del porteador. 3.2.B. La responsabilidad del porteador. 3.2.B.a Daños personales a los viajeros. 3.2.B.b Daños a los equipajes y bultos de mano. 3.2.B.c Cancelación, interrupción, retraso en la salida. 3.2.B.d Cuestiones procesales. 4. BIBLIOGRAFÍA.

\section{CONSIDERACIONES CONCEPTUALES PREVIAS}

El contrato de transporte terrestre de viajeros por carretera es aquel en el que una persona (porteador) se obliga, a cambio de un precio, a trasladar personas y, en su caso, sus equipajes, de un lugar a otro, en vehículos automóviles que circulen sin camino de rodadura fijo, y sin medios fijos de captación de energía, por toda clase de vías terrestres urbanas o interurbanas ${ }^{1}$. La prestación por cuenta propia o ajena y la onerosidad de la

\footnotetext{
${ }^{1}$ Dentro del transporte terrestre también incluimos, con las matizaciones que a continuación se expondrán, los eventuales transportes nacionales de viajeros que utilicen las rutas que marcan los ríos o el transporte lacustre, dada la ausencia de regulación específica y siguiendo la tradición de someterlo a la calificación y al régimen de los transportes terrestres. No obstante, en esta materia no podemos desconocer, por un lado, que el legislador europeo, en lo que se refiere al reconocimiento de derechos a los pasajeros, otorga un tratamiento uniforme a las vías marítimas y a las vías navegables, entendiendo por éstas las «masas, o sistema de masas interconectadas, de aguas interiores navegables, de carácter natural o artificial, que se utilizan para transporte, como lagos, ríos o canales o cualquier combinación de éstos» (en particular, el Reglamento 1177/2010, del Parlamento Europeo y del Consejo, de 24 de noviembre, sobre los derechos de los pasajeros que viajan por mar y por vías navegables — no aplicable a los circuitos de excursión y turísticos, excepto los cruceros, ni a los viajes combinados ni a los buques que transportan un máximo de 12 pasajeros - introduce un detallado sistema de compensaciones económicas en los supuestos de retraso y cancelación de salidas de ciertos de tipos de viajes, regulando también la información mínima que debe facilitarse a los pasajeros y la tramitación de las reclamaciones a que hubiere lugar). Y, por otro lado, que no se da un tratamiento jurídico uniforme a las eventuales responsabilidades derivadas de accidentes; en efecto, la Ley 14/2014, de 24 de julio, de Navegación Marítima (LNM), considera en su artículo $1 .^{\circ}$ que también es navegación marítima la que se lleva a cabo por las aguas de los ríos, canales, lagos, o embalses naturales o artificiales, cuando sean accesibles para los buques desde el mar, pero sólo hasta donde se haga sensible el efecto de las mareas, así como en los tramos navegables de los ríos hasta donde existan puertos de interés general, lo que implica la reclamación de la aplicación en este ámbito del régimen de responsabilidad del porteador del Convenio Internacional relativo al Transporte de Pasajeros y sus Equipajes por Mar, hecho en Atenas el 13 de diciembre de 1974 (PYE/PAL), con sus protocolos de modificación, así como del Reglamento 392/2009, del Parlamento Europeo y del Consejo, de 23 de abril, sobre la responsabilidad de los transportistas de pasajeros por mar en caso de accidente y de la propia LNM. La navegación por el resto de las aguas interiores se regirá por la legislación reguladora del dominio público hidráulico (Real Decreto Legislativo 1/2001, de 20 de julio, por el que se aprueba el texto refundido de la Ley de Aguas y el Real Decreto 849/1986, de 11 de abril, por el que se aprueba el Reglamento del Dominio Público Hidráulico) y por las demás disposiciones que le sean de aplicación. La legislación reguladora del dominio público hidráulico, además de regular los requisitos administrativos de acceso a la actividad de navegación (requiriéndose bien la previa declaración responsable para el acceso a usos comunes especiales
} 
realización del transporte constituyen las condiciones esenciales de la existencia de un contrato mercantil de transporte de personas, pues junto a la profesionalidad del transportista y disponibilidad de los medios adecuados para el desarrollo efectivo de la actividad de transportar (vehículos, conductores profesionales, etc.), es precisamente lo que permite distinguir los transportes privados, bien los particulares o los complementarios de una actividad empresarial cuyo objeto no sea el transporte (artículos 62.3 y 100 a 105 Ley 16/1987, de 30 de julio, de Ordenación de los Transportes Terrestres, LOTT; artículos 156 a 158 de su Reglamento de desarrollo, aprobado por RD 1211/1990, de 28 de septiembre; ROTT), del transporte público (artículo 62.2 LOTT), explotado como actividad mercantil, y justifica el mantenimiento de una regulación autónoma para cada tipo en nuestro ordenamiento jurídico.

El contrato de transporte terrestre de viajeros no difiere del contrato de transporte de cosas, participando de la naturaleza jurídica propia de los contratos de obra, en los que lo relevante en cuanto a la identificación de la prestación objeto de la obligación, es decir, lo que es debido, es el resultado ${ }^{2}$; y, para cumplir exactamente la obligación, el deudor debe alcanzar el fin pactado. Particularmente, queda enmarcado en la categoría de la locatio operis, como subespecie del arrendamiento de obra, caracterizado por el tipo del resultado prometido. Esta calificación no impide que el deudor, necesariamente en este tipo de contrato, además de obligarse a la consecución de un resultado final, se obligue, al mismo tiempo, al ejercicio de una cierta actividad con la diligencia necesaria, que no

como la navegación, incluida la recreativa en embalses, y establecimiento de barcas de paso; o bien, sometiendo al régimen de concesión administrativa el uso privativo de las aguas para usos recreativos, de navegación y de transporte acuático), se limita a atribuir a quienes presenten declaraciones responsables para navegar la responsabilidad de que sus embarcaciones cumplan con la legislación vigente en cuanto a estabilidad de las mismas, elementos de seguridad y buen estado de conservación y a exigir el aseguramiento obligatorio contra daños a terceros de las embarcaciones de propulsión a motor o vela con eslora superior a cuatro metros.

${ }^{2}$ En este sentido, vid., por todos, PILOÑETA ALONSO, L. M., «El contrato de transporte terrestre de personas: Fundamentos de su régimen jurídico, elementos y contenido», en AA.VV., Régimen Jurídico del Transporte Terrestre: Carreteras y Ferrocarril, dir. por MENÉNDEZ GARCÍA, P., T. II, Aranzadi Thomson Reuters, Navarra, 2014, págs. 861 a 871; DÍAZ MORENO, A., «El contrato de transporte terrestre nacional de mercancías», en AA.VV., Derecho mercantil, Vol. $8^{\circ}$ (Transportes mercantiles), coord. por JIMÉNEZ SÁNCHEZ, G. - DÍAZ MORENO, A., Marcial Pons, Madrid, 2014, págs. 245 y 246; URÍA, R., Derecho mercantil, Marcial Pons, Madrid, 2001, pág. 703; SÁNCHEZ CALERO GUILARTE, J. SÁNCHEZ CALERO, F., Instituciones de Derecho Mercantil, Vol. II, Aranzadi Thomson Reuters, Pamplona, 2015, pág. 479; PEINADO, J.I., «El Contrato de Transporte Terrestre (I). El transporte de mercancías y viajeros por carretera», en AA.VV., Lecciones de Derecho Mercantil, dir. por MENÉNDEZ, A. - ROJO, A., Civitas, Pamplona, 2019, pág. 172.

Sobre las obligaciones de resultado, vid. GULLÓN, A., Curso de Derecho civil. El negocio jurídico, Madrid, 1969, págs. 178; JORDANO FRAGA, J. «Obligaciones de medios y de resultado (A propósito de alguna jurisprudencia reciente)», Anuario de Derecho Civil, 1991, págs. 7 y ss.; LOBATO GÓMEZ, J.M., «Contribución al estudio de la distinción entre obligaciones de medios y obligaciones de resultado», Anuario de Derecho Civil, 1992, págs. 651 y ss; CABANILLAS SÁNCHEZ, A., Las obligaciones de actividad y de resultado, Barcelona, 1993, pág. 38; BLANCO PÉREZ-RUBIO, L. «Obligaciones de medios y obligaciones de resultado: ¿tiene relevancia jurídica su distinción?», Cuadernos de Derecho Transnacional, Vol. 6, núm. 2, 2014, págs. 50 a 74; ROZO SORDINI, P.E, «Las obligaciones de medios y de resultado y la responsabilidad de los médicos y los abogados en el derecho italiano», Revista de Derecho Privado, núm. 4, 1999, págs. 139 a 142. 
deja por ello de ser instrumental.

Se trata, en definitiva, de un contrato de transporte cuya especialidad radica en el objeto sobre el cual el porteador ha de desarrollar su actividad. La singularidad del objeto, esto es, las personas, influye en el régimen de la responsabilidad del porteador, pues a éste le es imposible controlar de manera absoluta la conducta de los viajeros, que pueden sufrir daños por imprudencia propia.

En cuanto a sus caracteres, se trata de un negocio jurídico consensual, bilateral, sinalagmático, oneroso y mercantil. Según la tipología del transporte, será de tracto único (servicios regulares de uso general) o de tracto sucesivo (servicios regulares especiales y, generalmente, los servicios discrecionales), de adhesión y formal ad probationem (servicios regulares de uso general).

En efecto, el contrato de transporte terrestre de personas es consensual, de modo que se perfecciona por el mero consentimiento de las partes. No obstante, en ocasiones por imperativo legal y, en otras, por constituir una práctica habitual, se expide un documento, ya sea en papel o electrónicamente — «billete», normalmente emitido al portador y de forma individual - que no goza de las características de los títulos-valores. Se trata de un título de legitimación que opera el conocido efecto de legitimación activa, de tal forma que se considerará como persona que ha contratado el transporte aquélla que se presente en el momento de comenzar el viaje con el billete o que lo adquiera al acceder al mismo. No obstante, como no se produce «incorporación» del derecho al documento, es posible que el titular ejerza el derecho a que se refiere sin la exhibición del documento (y sin necesidad de procedimiento alguno de amortización). Además, acreedor y deudor (viajero y porteador) pueden recurrir a elementos extraños al documento (el contrato de transporte) para determinar el contenido, alcance y las condiciones del derecho. En términos generales, en los servicios regulares de uso general la emisión del billete se eleva a requisito formal ad probationem. En los servicios discrecionales o en los regulares especiales no se precisa por regla general la emisión del billete individual en favor del viajero, pues entre el organizador del transporte y el porteador y, a su vez, entre el viajero y el organizador mediará el contrato correspondiente ${ }^{3}$.

Por otro lado, para los transportes en autobús o autocar con embarque o desembarque dentro de la Unión Europea, tanto discrecionales como los regulares cuya distancia programada sea igual o superior a $250 \mathrm{~km}$., el Reglamento (UE) núm. 181/2011 del Parlamento Europeo y del Consejo, de 16 de febrero, sobre los derechos de los viajeros de autobús y autocar, contempla que los transportistas emitan necesariamente un billete al viajero, a menos que otros documentos concedan el derecho al transporte, pudiendo documentarse en formato electrónico. Por su parte, sin limitación de distancias, respecto al transporte regular de uso general internacional y de cabotaje, el Reglamento (CE) núm. 1073/2009, del Parlamento Europeo y del Consejo, de 21 de octubre, por el que se

\footnotetext{
${ }^{3}$ PILOÑETA ALONSO, L. M., «El contrato de transporte terrestre de personas: Fundamentos de su régimen jurídico, elementos y contenido», op. cit., págs. 891 a 900.
} 
establecen normas comunes de acceso al mercado internacional de los servicios de autocares y autobuses, contempla que los transportistas expidan títulos de transporte individuales o colectivos que indiquen: a) los puntos de partida y de destino y, en su caso, el regreso; b) el período de validez del título de transporte, y c) la tarifa de transporte.

Finalmente, en caso de que se haya pactado el transporte de equipaje facturado, habrá que emitir un documento específico o, al menos, incorporar esta circunstancia en el billete, de modo que el viajero pueda legitimarse para solicitar la restitución del equipaje entregado al porteador para su transporte complementario.

\section{RÉGIMEN JURÍDICO Y MODALIDADES DE TRANSPORTE TERRESTRE POR CARRETERA}

El contrato de transporte terrestre de viajeros carece de regulación expresa en las normas jurídico privadas de nuestro ordenamiento ${ }^{4}$. Más allá de la posible aplicación analógica de los preceptos del Código civil dedicados a los transportes terrestres no sometidos a la legislación mercantil, artículos 1601 a 1603, y de la aplicación de los generales del arrendamiento de obra y del Texto Refundido de la Ley General para la Defensa de los Consumidores y Usuarios y otras leyes complementarias, aprobado por Real Decreto Legislativo 1/2007, de 16 de noviembre (en adelante, TRLGDCU), así como de la Ley 7/1998, de 13 de abril, de Condiciones Generales de la Contratación, en caso de contratos de adhesión, sólo en las normas jurídico públicas encontramos referencias normativas expresas al transporte de viajeros por carretera.

Así, con independencia de las normativas autonómicas y locales en sus respectivos ámbitos de competencia en aquellos transportes que se desarrollan exclusivamente en dichos espacios, la Ley 16/1987, de 30 de julio, de Ordenación de los Transportes Terrestres (en adelante, LOTT) y su Reglamento de desarrollo (aprobado por R.D. 1211/1990, de 28 de septiembre, en adelante, ROTT), regulan, entre otros extremos, las condiciones para el ejercicio de la actividad (arts. 21, 42 a 46, 63 a 65, 67, 70 a 86, 89, 91, 94, 95 y 99 LOTT), los transportes turísticos (arts. 110 a 112 LOTT) y los transportes internacionales (arts. 65, 106 a 108 LOTT). Los citados preceptos de la LOTT referidos al transporte de viajeros han sido objeto de una intensa revisión a través de la Ley 9/2013, de 4 de julio, atendiendo a los cambios experimentados por el mercado de transporte terrestre de viajeros, tanto en el ámbito nacional como en el de la Unión Europea. A tal efecto, se incorporaron al texto de la LOTT las exigencias introducidas por el Reglamento (CE) núm. 1071/2009, del Parlamento Europeo y del Consejo, de 21 de octubre, por el

\footnotetext{
${ }^{4}$ Vid. QUINTANA CARLO, I., «La regulación del transporte terrestre de viajeros y la desidia del legislador español», Revista del Derecho del Transporte, núm. 16 (2015), págs. 11 a 29, donde critica la ausencia de una ley formal en nuestro derecho nacional que regule el contrato de transporte terrestre de personas. Cuestiona además el posicionamiento del Ministerio de Fomento en contra de la inclusión en la propuesta de Anteproyecto de Código Mercantil elaborado por el Grupo XI de la Comisión General de Codificación, de la regulación del contrato de transporte de personas. Vid., además, QUINTANA CARLO, I., «Hacia una regulación unitaria del transporte de personas», en AA.VV., El contrato de transporte de viajeros, nuevas perspectivas, dir. por ZUBIRI SALINAS, M., Aranzadi Thomson Reuters, Pamplona, 2016, págs. 21 a 45.
} 
que se establecen normas comunes relativas a las condiciones que han de cumplirse para el ejercicio de la profesión de transportista por carretera y por el Reglamento (CE) núm. 1073/2009, del Parlamento Europeo y del Consejo, de 21 de octubre, por el que se establecen normas comunes de acceso al mercado internacional de los servicios de autocares y autobuses. Por otro lado, se adaptó el régimen de gestión de los transportes públicos regulares de viajeros de uso general por carretera y ferrocarril a las reglas contenidas en el Reglamento (CE) núm. 1370/2007, del Parlamento Europeo y del Consejo, de 23 de octubre, sobre los servicios públicos de transporte de viajeros por ferrocarril y carretera.

Dentro del transporte terrestre por carretera encontramos distintas tipologías, según el transporte sea regular o discrecional o, siendo de una u otra clase, éste se encuadre en la categoría de transporte turístico, transporte interior, internacional o de cabotaje. Aunque todas las modalidades del transporte público de viajeros, excepto el realizado en vehículos cuya velocidad máxima autorizada no supere los 40 kilómetros por hora, quedan sometidas a la exigencia general de la posesión de una autorización que habilite para ello, expedida por el órgano competente de la Administración General del Estado o, en su caso, por el de aquella Comunidad Autónoma en que se domicilie dicha autorización (artículo 42 LOTT $)^{5}$, encontramos diferencias en cuanto a su respectivo régimen jurídico que justifican su distinción:

a) Los transportes públicos regulares se efectúan dentro de itinerarios preestablecidos, y con sujeción a calendarios y horarios prefijados. A su vez, en función de su utilización, estos servicios regulares se clasifican entre:

i) Transportes públicos regulares de uso general, que van dirigidos a satisfacer una demanda general y se contratan por plaza o asiento, siendo utilizables sin discriminación por cualquier interesado. El artículo 71 LOTT les atribuye el carácter de servicio público de titularidad de la Administración ${ }^{6}$. El contratista de un servicio público de transporte regular de viajeros de uso general está obligado a transportar a todas aquellas personas que lo soliciten, y abonen el precio del transporte, expidiendo el correspondiente título de viaje, salvo que ello implicase

\footnotetext{
${ }^{5}$ Vid., al respecto RAZQUIN LIZARRAGA, J.A., Derecho público del transporte por carretera, Aranzadi Thomson Reuters, Pamplona 1995; AGOUÉS MENDIZABAL, C., «La intervención administrativa en el transporte de viajeros por carretera», Revista del Derecho del Transporte núm. 7 (2015), págs. 74 a 82.

Para conocer la situación actualizada del sector, consúltese el Informe «Observatorio del transporte de viajeros por carretera. Oferta $y$ demanda (enero 2021)» en https://www.mitma.gob.es/recursos_mfom/comodin/recursos/observatorio_viajeros__oferta_y_demanda_enero_2021.pdf y el informe «Observatorio del transporte de viajeros por carretera. Contratos de Gestión de la Administración General del Estado (noviembre 2020)》 en https://www.mitma.gob.es/recursos_mfom/comodin/recursos/observatorio_2019.pdf .

6 Vid., al respecto, BLANQUER CRIADO, D.V., «El transporte de viajeros por carretera: servicio económico de interés general y libertad de empresa; las obligaciones de servicio público», en AA.VV., Régimen jurídico del transporte terrestre: carreteras y ferrocarril, dir. por MENÉNDEZ GARCÍA, P., T. I, Aranzadi Thomson Reuters, Pamplona, 2014, págs. 691 a 750; GUILLÉN CARAMÉS, J., «Los derechos de los usuarios de transportes terrestres por carretera y ferrocarril», en AA.VV., Régimen jurídico del transporte terrestre: carreteras y ferrocarril, op. cit., págs. 38 a 42.
} 
sobrepasar las plazas ofrecidas en la expedición de que se trate. El contratista únicamente podrá impedir la utilización del servicio por un viajero que estuviese en posesión del correspondiente título de viaje cuando la persona o su equipaje no reúnan las condiciones mínimas de sanidad, salubridad e higiene; cuando porten objetos que por su volumen, composición u otras causas supongan peligro o incomodidad para los otros viajeros o el vehículo; o cuando altere las normas elementales de educación y convivencia.

Como regla general, la prestación de estos servicios se llevará a cabo por la empresa a la que la Administración adjudique el contrato de gestión de servicio público de transporte regular de viajeros de uso general en la modalidad de concesión de servicios ${ }^{7}$, pudiendo no obstante ser gestionados mediante otras fórmulas o ser prestados directamente por la Administración a través de medios propios. Según establece el artículo 22 LOTT, la prestación de los transportes de viajeros que tengan atribuido el carácter de servicio público de titularidad de la Administración sólo podrá ser contratada en concepto de porteador por el contratista a quien el órgano competente hubiese adjudicado su gestión o, en su caso, por el ente, organismo o entidad que la Administración competente haya creado para la gestión o coordinación de esa clase de servicios.

Precisamente por la consideración de estos transportes como servicio público, pueden converger dos relaciones jurídicas de naturaleza diversa, esto es, la del usuario y la Administración titular del servicio, regulada por las normas de Derecho público, y la del usuario con la empresa concesionaria del servicio, a la que se aplicarán las normas jurídico privadas, en particular, las de consumo. El empresario pasa a gestionar un servicio de titularidad de la Administración, estableciéndose las relaciones directamente entre el usuario del servicio y el empresario, que asume además el riesgo operacional.

ii) Transportes públicos regulares de uso especial, destinados a servir, exclusivamente, a un grupo específico de usuarios tales como escolares, trabajadores, militares, o grupos homogéneos similares que tengan un único centro concreto de actividad común, en el que el transporte tenga su origen o destino; la prestación de estos transportes queda sometida a un régimen de autorización especial por parte de la Administración, supeditado a que la empresa transportista haya convenido previamente con los usuarios la realización del transporte a través del oportuno contrato o precontrato, y coincidiendo el plazo de la autorización con el de la duración del contrato (artículo 89 LOTT).

\footnotetext{
${ }^{7}$ Vid., al respecto, AGOUÉS MENDIZABAL, C., op. cit., págs. 82 a 85; CARBONELL PORRAS, E., Régimen jurídico-administrativo del transporte interurbano por carretera, Madrid, 1993, págs. 221 a 228; VALCÁRCEL FERNÁNDEZ, P., «Régimen jurídico del transporte terrestre de mercancías y viajeros por carretera», en AA.VV., Derecho de la regulación económica, dir.por MUÑOZ MACHADO, S., Vol. 6, 2010 (Transportes), págs. 11 a 308.
} 
b) Por su parte, los transportes públicos discrecionales se llevan a cabo sin sujeción a itinerario, calendario ni horario preestablecido y son contratados, como regla general, por toda la capacidad del vehículo utilizado, salvo supuestos excepcionales de contratación por plaza con pago individual. En este sentido, se podrá autorizar, bien con carácter único o temporal, la contratación por plaza con pago individual cuando se den conjuntamente, al menos, tres de las cuatro siguientes circunstancias: que el transporte venga motivado por acontecimientos de afluencia masiva de público, no pudiendo la demanda ser satisfecha por los servicios regulares de uso general; que por su carácter ocasional no proceda el establecimiento de transportes regulares o de uso especial; que no se presten con reiteración de itinerario, calendario y horario, teniendo cada transporte una finalidad específica e independiente; o que el transporte se organice con un objetivo o finalidad común a la totalidad de los viajeros.

Los transportes públicos discrecionales se someten igualmente a un régimen de autorización (artículos 91 y 99 LOTT), que habilitará, en su caso, para realizar servicios en todo el territorio nacional y para intermediar en su contratación.

Dentro de los transportes públicos discrecionales, se incluyen tanto el arrendamiento de vehículos de turismo con conductor (artículo 99.4 LOTT y artículos 180 a 182 ROTT), como los servicios que tienen por objeto conectar mediante aplicaciones para teléfonos inteligentes, a cambio de una remuneración, a conductores no profesionales que utilizan su propio vehículo con personas que desean efectuar un desplazamiento. Esta actividad ha sido calificada como servicio en el ámbito de los transportes [STJUE 20 de diciembre de 2017, asunto C-434/15; también la STS 87/2018, de 25 de enero (TOL6.489.167)] y no como un mero servicio de intermediación, en atención a que este servicio no responde a la calificación de «servicio de la sociedad de la información» sino a la de «servicio en el ámbito de los transportes» dada la labor de organización del servicio subyacente de transporte que realizan las plataformas y la influencia decisiva sobre las condiciones de su prestación (desde el establecimiento de condiciones de acceso y selección de los conductores, la fijación del precio del transporte, la gestión de los trayectos, el sometimiento de los conductores a sus instrucciones y control, etc.). La consideración de dicha actividad como una modalidad más de transporte discrecional de viajeros dentro de la modalidad de arrendamiento de vehículo con conductor, implica que se condicione su ejercicio a la obtención de la correspondiente autorización, de conformidad con lo dispuesto en el artículo 42 LOTT. Además de las posibles responsabilidades administrativas derivadas de incumplimientos de dichas exigencias, las plataformas responderán frente a los viajeros según el régimen de responsabilidad del porteador, y también por los daños y perjuicios causados a terceros por negligencia o imprudencia en la prestación del servicio de transporte, tanto en el ámbito civil como, en su caso, el penal ${ }^{8}$.

\footnotetext{
8 Vid., para mayor amplitud, LÓPEZ ORTEGA, R., «Las plataformas Uber, BlaBlaCar y Airbnb ¿Intermediarias o prestadoras del servicio subyacente?», Revista de Derecho Mercantil, núm. 321, 2021. Asimismo, GORRIZ LÓPEZ, C., «Uber. Transporte de pasajeros y competencia desleal», Revista de Derecho del Transporte, núm.16 (2015), págs. 77 a 98; GORRIZ LÓPEZ, C., "Taxi vs Uber: De la competencia desleal al arrendamiento de vehículo con conductor", Revista de Derecho mercantil, núm. 311, 2019, págs. 241 y ss.; GUILLÉN NAVARRO, N.A., «El arrendamiento de vehículos con conductor
} 
c) Por transporte turístico entiende la LOTT (artículo 110) aquel que se realiza en el marco de la ejecución de un viaje combinado ofertado o que, sin tener una duración superior a las veinticuatro horas y sin incluir una pernoctación, se oferte a través de agencias de viajes, $\mathrm{u}$ otros intermediarios turísticos, y se preste conjuntamente con otros servicios complementarios de naturaleza turística, tales como los de manutención, guía turístico o similar. El régimen legal se limita, por un lado, a impedir que la oferta turística modifique las condiciones de prestación del transporte regular de viajeros como servicio público y la competencia injustificada de precios entre el transporte turístico y el regular; $\mathrm{y}$, por otro, a prever para los discrecionales una futura reglamentación de un régimen especial que armonice las reglas generales de aplicación al transporte discrecional con las especiales características que presenta la prestación del conjunto de servicios que integran un viaje combinado. Los transportes turísticos podrán ser objeto de contratación individual y cobro por asiento, facilitando a cada viajero un billete en el que se especificará que se trata de un servicio turístico, el trayecto que comprende, las prestaciones complementarias incluidas y el precio total. Tendrán, asimismo, el carácter de turísticos los transportes de viajeros por carretera con origen o destino en aeropuertos, puertos o estaciones ferroviarias, contratados con agencias de viaje conjuntamente con el correspondiente transporte aéreo, marítimo o ferroviario, como continuación o antecedente de éste, siempre que el precio del transporte por carretera no exceda del 40 por 100 del realizado en el otro modo.

d) En el transporte público internacional de viajeros por carretera, esto es, aquél cuyo itinerario discurre parcialmente por el territorio de Estados extranjeros, podemos distinguir los siguientes tipos de servicios: i) Servicios regulares, que son aquéllos que aseguran el transporte de personas con una frecuencia y un itinerario determinados; ii) Servicios regulares especializados destinados al transporte de determinadas categorías de viajeros con exclusión de otros; iii) Servicios de lanzadera, que son aquéllos que se organizan para transportar en varios viajes de ida y de regreso, desde un mismo punto de partida a un mismo punto de destino, a viajeros previamente constituidos en grupos; iv) Servicios discrecionales: son los servicios que no corresponden ni a la definición de

(VTC) y su entramado jurídico: el avance de Uber, Cabify y la economía colaborativa», Revista de Estudios de la Administración Local y Autonómica. Nueva Época, núm. 9, 2018, págs. 128 a 147; LÓPEZ GARCÍA DE LA SERRANA, J., "La consideración jurídica del servicio prestado por la plataforma Uber a la luz de la Jurisprudencia del TJUE", en AA.VV., Propuestas de regulación de las plataformas de economía colaborativa: Perspectivas general y sectoriales, dir. por RUBIO GIMENO, G. - ORTÍ VALLEJO, A., Aranzadi, Navarra, 2019, págs. 325 y ss.; FINCK, M. (2018). «Distinguishing internet platforms from transport services: Elite Taxi v. Uber Spain», Common Market Law Review, Vol. 55, núm. 5, págs. 1619 a 1640; RUDA GONZÁLEZ, A. «Responsabilidad por hechos ajenos en la economía colaborativa. El caso de UBER», en AA.VV., Collaborative Economy. Challenges \& Opportunities, coord. por BALCELLS, J., Huygens Editorial Barcelona, 2018, págs. 424 a 440; RODRÍGUEZ MARÍN, S. «Aspectos jurídicos de la economía colaborativa y bajo demanda en plataformas digitales», en AA.VV., Aspectos legales de la economía colaborativa y bajo demanda en plataformas digitales, coord. por RODRÍGUEZ MARÍN, S. MUÑOZ GARCÍA, A., Bosch, Las Rozas (Madrid), 2018, págs. 43 a 76; TOURIÑO, A., «Régimen de responsabilidad de las plataformas que operan en el ámbito de la economía colaborativa», en AA.VV., Aspectos legales de la economía colaborativa y bajo demanda en plataformas digitales, op. cit., págs. 77 a 101; PAZOS CASTRO, R., «Uber, Airbnb y la llamada "influencia decisiva” de las plataformas digitales», Revista de Internet, Derecho y Política, núm. 31, 2020, págs. 1 a 14. 
servicio regular ni a la definición de servicio de lanzadera y que se caracterizan, fundamentalmente, por el hecho de transportar grupos formados por encargo o por el propio transportista.

En materia de transporte internacional y de cabotaje, la LOTT opta básicamente, por remitirse a las reglas contenidas en el citado Reglamento (CE) núm. 1073/2009 — que, partiendo de la libre prestación de servicios, establece el régimen de la licencia comunitaria para el porteador y somete al transporte regular general a un régimen de autorización específica y, en los casos en los que no exista contrato entre el porteador y el organizador, también a los servicios regulares de carácter especial- y a las reglas que, en su caso, resulten de aplicación de los convenios internacionales suscritos por España. Así, el artículo 106 LOTT se remite, en cuanto a la regulación de los servicios de transporte internacional que discurran parcialmente por territorio español utilizando vehículos que no se hayan matriculado en España, a lo dispuesto en los convenios internacionales. En cuanto a las empresas establecidas en España, el artículo 108 LOTT supedita la obtención de títulos habilitantes para realizar transporte internacional cuyo otorgamiento corresponda al Estado español, incluida la licencia comunitaria, a la previa autorización de transporte bien regular o discrecional en el ámbito nacional. Y el artículo 107, referido al transporte de cabotaje, entendiendo por éste un transporte nacional por cuenta ajena llevado a cabo con carácter temporal por vehículos que no estén matriculados en España, no entra sin embargo a regularlo, remitiéndose a lo dispuesto acerca de los transportes de cabotaje en la reglamentación europea —en este caso, no sólo los artículos 14 a 17 del Reglamento (CE) núm. 1073/2009, sino también el Reglamento (CE) núm. 561/2006, del Parlamento Europeo y del Consejo, de 15 de marzo, relativo a la armonización de determinadas disposiciones en materia social en el sector de los transportes por carretera - o en los convenios internacionales suscritos por España. Respecto a los convenios internacionales, sin mencionar los de carácter bilateral, destaca el Convenio de Bruselas de 3 de octubre de 2002 sobre el transporte discrecional internacional de los viajeros en autocar y en autobús (Interbús) que, sustituyendo los acuerdos bilaterales suscritos entre las partes contratantes, en general, liberaliza los servicios discrecionales cuando el transporte se realice en el Estado del transportista o tenga como origen o destino un Estado parte del Convenio. El Convenio entró en vigor el 1 de enero de 2003, habiendo sido posteriormente actualizado mediante la Decisión núm. 1/2011 del Comité Conjunto (artículo 24, apartado 2, letra b). La Unión Europea es parte contratante del Convenio Interbús.

Tal y como se ha expuesto, el control ejercido por la Administración y la especial naturaleza de los servicios de transporte de viajeros aparta el régimen jurídico privado de estas operaciones (que se mantiene con carácter residual, por ejemplo, a la hora de refrendar el principio de la libertad de contratación en relación con la prestación de servicios de carácter discrecional —art. 94.1 LOTT-), a favor de un régimen esencialmente público.

También es reseñable, en este ámbito, la posible elaboración o aprobación de contratos- 
tipo o condiciones generales de la contratación de los transportes por carretera de viajeros por el Ministerio competente en materia de transportes, en virtud de la previsión del artículo 13 del ROTT, al igual que se han aprobado para el transporte de mercancías por carretera (Orden FOM 1882/2012, de 1 de agosto) ${ }^{9}$. Hay que destacar el distinto alcance jurídico de dichos contratos-tipo o condiciones generales según el tipo de contratación, partiendo siempre de su carácter de condiciones mínimas que pueden modificarse en favor de los usuarios (artículo 13.2 y 3 ROTT): así, cuando se refieran a transportes de viajeros en autobús contratados por coche completo -incluyéndose los regulares de uso especial-, o a arrendamiento de vehículos con conductor, serán aplicables en forma subsidiaria o supletoria a las que libremente pacten las partes de forma escrita en los correspondientes contratos singulares; mientras que en los transportes de viajeros por carretera en vehículos de turismo o en autobús con contratación por asiento, esto es, los contratos de transporte regulares de uso general, los contratos-tipo o condiciones generales de contratación aprobados, en su caso, por la Administración, se aplicarán con carácter imperativo, pudiendo, no obstante, incluirse cláusulas anexas a dichos contratostipo que se apliquen únicamente con carácter subsidiario o supletorio a los que pacten las partes.

El contrato de transporte de personas, por su propia naturaleza, tampoco es objeto de regulación por la Ley 15/2009, de 11 de noviembre, del contrato de transporte terrestre de mercancias (en adelante, LCTTM). No obstante, hay que tener en cuenta lo dispuesto en su disposición adicional segunda que, refiriéndose a los transportes mixtos, esto es, a aquéllos en los que se combina el transporte de viajeros (siendo éste comúnmente el principal en la relación y el que la caracteriza) con el de mercancías, se declara aplicable respecto del transporte de éstas. En este ámbito es preciso distinguir entonces entre el equipaje en sentido estricto de los viajeros, del que viaja en las bodegas o zonas habilitadas para la carga del vehículo, el equipaje de mano, que viaja acompañando al viajero y bajo su custodia, en la propia cabina, y las mercancías, referidas a cualquier objeto que no guarde relación directa con ninguno de los viajeros que ocupan plaza en el vehículo. De ello se deduce la inaplicabilidad de esta Ley 15/2009 a cualquier objeto cargado por un viajero, sea cual fuere su naturaleza y finalidad del viaje, transporte que quedará sometido a las normas del transporte de viajeros, esto es, a la LOTT y su reglamento de desarrollo.

Por último, en el ámbito europeo, destaca el Reglamento (UE) núm. 181/2011, del Parlamento Europeo y del Consejo, de 16 de febrero, sobre los derechos de los viajeros de autobús y autocar ${ }^{10}$ [en adelante, Reglamento (UE) núm. 181/2011], que es aplicable

\footnotetext{
9 ESTANCONA PÉREZ, A.A., Transporte Terrestre de pasajeros. Contratación, responsabilidad y seguro, Tirant lo Blanch, Valencia 2018, págs. 62 a 66.

${ }^{10}$ Esta norma se enmarca dentro de la política común de transportes de pasajeros, en la que se aboga indudablemente por la unificación del régimen jurídico del transporte de viajeros con independencia del medio (terrestre, marítimo o aéreo) que se utilice y del ámbito geográfico en el que se desarrolle.
}

De un lado, estamos asistiendo en los últimos años a un intenso esfuerzo del legislador internacional y de la Unión Europea por adecuar la regulación del transporte de personas a la situación actual del tráfico e incrementar la tutela de los intereses de los pasajeros sobre la base de que se garantice un elevado nivel de 
-aunque con distinto alcance- tanto a los servicios regulares como a los discrecionales; a saber: a) Servicios regulares: se aplica en su totalidad la norma europea a los viajeros que utilicen servicios regulares para viajeros de categoría indeterminada cuyo punto de embarque o desembarque esté situado en el territorio de un Estado miembro y cuya distancia programada sea igual o superior a $250 \mathrm{~km}$. Para los servicios cuya distancia programada sea inferior a $250 \mathrm{~km}$, sólo se aplicarán el artículo 4.2 (condiciones contractuales no discriminatorias); los artículos 9. ${ }^{\circ}$ y 10.1 (derecho al transporte y excepciones); el artículo 16.1.b y 2 (formación de conductores); el artículo 17.1 y 2 (indemnizaciones por pérdidas de equipos de movilidad), y el capítulo $\mathrm{V}$ (normas generales sobre información y reclamaciones) y artículo 28 (organismos nacionales de aplicación). b) Servicios discrecionales: La norma europea abarca en su ámbito de aplicación los servicios discrecionales cuando el punto de embarque inicial o el punto de desembarque final del viajero esté situado en el territorio de un Estado miembro, a excepción de sus artículos 9. a 16 y 17, apartado 3 (relativos a los derechos de las personas con discapacidad y movilidad reducida - sin incluir la excepción a las indemnizaciones por pérdidas de equipos de movilidad-) y de los capítulos IV (derechos

protección de los viajeros, comparable entre los distintos modos de transporte e independiente del lugar al que viajen. Así, los convenios internacionales relativos a la responsabilidad de los transportistas de personas en los distintos medios han sufrido en la última década modificaciones importantes estableciéndose soluciones sustancialmente similares. De la mano de la política común europea de transportes, también se ha producido una suerte de unificación del régimen jurídico aplicable tanto en el transporte interno de cada uno de los Estados que integran la Unión Europea como en el intracomunitario - y por ende, internacional-, mediante la técnica legislativa de incorporar los Convenios internacionales existentes al respecto a reglamentos comunitarios que extienden su aplicación no sólo a los trayectos dentro de la Unión Europea sino a los transportes nacionales o interiores. Tal y como se destaca en la Comunicación de la Comisión al Parlamento Europeo y del Consejo «Perspectiva europea de los pasajeros: Comunicación sobre los derechos de los pasajeros en todos los modos de transporte» (COM/2011/0898 final) en la Unión Europea existe un conjunto completo e integrado de normas básicas de los derechos de los pasajeros en todos los modos: aéreo, ferroviario, marítimo y fluvial y por carretera, que proporciona una protección mínima para los ciudadanos basada en tres pilares: la no discriminación, la información precisa, oportuna y accesible, y la asistencia inmediata y proporcionada. Vid., al respecto, MAMBRILLA RIVERA, V., «La política europea de transportes (Hacia el establecimiento de un Espacio Único Europeo del Transporte)», Revista de Derecho del Transporte, núm. 9 (2012), págs. 37 a 84.

De otro lado, y aun cuando en el transporte de personas existen regulaciones específicas en atención a los distintos medios empleados, en todas ellas encontramos una base común y una gran cantidad de afinidades en el régimen jurídico aplicable (incremento de los deberes legales de información, de asistencia al viajero y de accesibilidad, la distinción entre porteador contractual y porteador efectivo, la delimitación del período de responsabilidad, el alcance de la obligación de protección de los pasajeros, una tendencia a la objetivación de la responsabilidad, el reconocimiento de derechos de anticipo, etc.), a pesar de algunas diferencias en materia de presupuestos de la responsabilidad del porteador y límites cuantitativos de la misma.

Es de destacar que el Parlamento Europeo en su Resolución de 23 de octubre de 2012, sobre los derechos de los pasajeros en todos los modos de transporte (2012/2067 INI) recomienda la elaboración de un Marco de Referencia Común (MRC) para la legislación relativa a los pasajeros que, siguiendo el ejemplo del MRC sobre el Derecho contractual europeo, contenga los principios, las definiciones y las normas tipo de la legislación en este ámbito para todos los modos de transporte, y de una Carta de los derechos de los pasajeros, todo ello a fin de constituir una base para una mayor consolidación de la legislación relativa a los pasajeros y facilitar el ejercicio efectivo de los derechos. Partiendo de la instauración actual de la Unión Europea como área integrada de derechos de los pasajeros en todos los modos de transporte por primera vez en el mundo, el Parlamento europeo propugna finalmente convertir la política común de transportes de pasajeros, que sigue por ahora una estrategia puramente modal, en una política con una estrategia intermodal. 
de los viajeros en caso de cancelación o retraso), V (normas generales sobre información y reclamaciones) y VI (aplicación y organismos nacionales de aplicación).

\section{CONTENIDO OBLIGACIONAL Y RÉGIMEN DE RESPONSABILIDAD EN EL TRANSPORTE DE VIAJEROS POR CARRETERA}

En el transporte de personas desaparecen — por contraste con los elementos personales del transporte de mercancías - las clásicas figuras del cargador y del destinatario (salvo por lo que respecta al equipaje facturado) y aparece la figura del viajero que es el acreedor del transporte, en tanto que adquiere el derecho a ser transportado en las condiciones pactadas con el porteador.

En el transporte regular permanente de uso general, en la mayoría de los casos, es el viajero quien contrata directamente el transporte con el porteador y asume la obligación principal del pago del precio, aunque haya supuestos en los que la contratación se efectúe por persona distinta del viajero, pero a favor de éste, como supuesto clásico de las estipulaciones a favor de tercero. En los transportes regulares de uso especial y en los transportes discrecionales, será el organizador de los mismos quien asuma la figura de contratante principal con el porteador $y$, en consecuencia, quien está obligado al precio del transporte; el viajero, en estos casos, es el beneficiario de la prestación de traslado.

Precisamente, el artículo 165, 2 y 3, del ROTT hace referencia al alcance jurídico de la actuación de las agencias de viaje en relación con la contratación de transportes de viajeros por carretera, diferenciando cuándo han de actuar como comisionistas, contratando en consecuencia en nombre del transportista (en los transportes regulares de viajeros, incluso en el supuesto especial de que éstos formen parte de viajes combinados), $\mathrm{y}$ cuándo han de contratar en nombre propio tanto con los transportistas como con los usuarios (en los transportes turísticos integrados en paquetes turísticos y, en general, con todo tipo de transportes discrecionales, incluidos los que se realicen con contratación individual o por asiento, siempre que revistan carácter ocasional y esporádico, y vayan dirigidos a un grupo homogéneo de usuarios, teniendo el transporte un objetivo o finalidad común a todos ellos).

En el ámbito de los transportes por autobús y autocar regulados por el Reglamento (UE) núm. 181/2011, se distingue entre transportista contractual y transportista ejecutor u otros operadores, atribuyendo - cuando el transporte $\mathrm{u}$ otras de las obligaciones contempladas en dicha norma han sido confiados a un transportista ejecutor, proveedor de billetes o a cualquier otra persona - la responsabilidad del cumplimiento de las obligaciones encomendadas, al transportista contractual, la agencia de viajes, el operador turístico o el gestor de la estación que haya delegado tales obligaciones, al margen de la responsabilidad de la parte ejecutante (artículo 5. $\left.{ }^{\circ}\right)^{11}$.

\footnotetext{
11 Sobre las distintas acepciones de porteador según su posición contractual, vid. más ampliamente, GABALDÓN GARCÍA, J. L., El concepto de porteador en el transporte de mercancías, Granada, 2003; PULIDO BEGINES, J. L., El concepto de porteador efectivo en el Derecho uniforme del transporte, Marcial Pons, Madrid, 2012; idem., «El concepto de porteador y la dualidad porteador contractual-
} 
Otra cuestión relevante en el ámbito del transporte de personas es la atribución al viajero de la condición de consumidor o usuario en todos los casos, esto es, independientemente de que actúe en un ámbito relacionado con su actividad comercial, empresarial, oficio o profesión. Adoptar un concepto amplio de consumidor o usuario en estos supuestos implica la extensión de la protección de la legislación de consumo, tomando en consideración al viajero en su condición de acreedor de la fase ejecutiva del transporte y su posición de debilidad durante dicha ejecución ${ }^{12}$. Esta cuestión está tan solo resuelta a nivel legislativo en el ámbito de los viajes combinados y servicios de viajes vinculados, pues el artículo 151.1.f TRLGDCU entiende por viajero a toda persona que "tiene intención de celebrar un contrato o derecho a viajar", considerándosele, en consecuencia, destinatario de las normas protectoras del Libro IV del TRLGDCU y, por ende, del resto de las normas aplicables en virtud de dicha condición (por ejemplo, protección contra cláusulas abusivas). Únicamente se excluye, de forma expresa, del ámbito de protección del Libro IV del TRLGDCU, los viajes combinados y los servicios de viaje vinculados contratados sobre la base de un convenio general para la organización de viajes de negocios entre un empresario y otra persona física o jurídica que actúe con fines relacionados con su actividad comercial o profesión (artículo 150.1.c TRLGDCU).

\subsection{Obligaciones y responsabilidad del viajero}

Aun cuando el artículo 40 de la LOTT anunciaba la elaboración por la Administración de un catálogo de los derechos y deberes de los usuarios del transporte, y el artículo 41 de dicho texto legal el establecimiento de las condiciones generales de utilización del servicio que habrán de cumplir los usuarios y de las obligaciones de los viajeros en la utilización de los transportes terrestres, dicho desarrollo aún no ha tenido lugar. En cambio, sí hace referencia a las normas generales de comportamiento en la circulación por parte de los usuarios, el artículo 2. ${ }^{\circ}$ del Real Decreto 1428/2003, de 21 de noviembre, por el que se aprueba el Reglamento General de Circulación para la aplicación y desarrollo del texto articulado de la Ley sobre tráfico, circulación de vehículos a motor y seguridad vial, aprobado por el Real Decreto Legislativo 339/1990, de 2 de marzo (en adelante, RGC), señalando que «[Los usuarios de la vía están obligados a comportarse de forma que no entorpezcan indebidamente la circulación ni causen peligro, perjuicios o molestias innecesarias a las personas, o daños a los bienes (art. 9.1 del texto articulado)]». Además, en el artículo 11 de dicho texto legal se detallan las prohibiciones que se imponen a los usuarios de los servicios públicos de transporte colectivo de personas. Distraer al conductor durante la marcha del vehículo; b. Entrar o salir del vehículo por lugares distintos a los destinados, respectivamente, a estos fines; c. Entrar en el vehículo

porteador sustituto en las CIM-1999», Revista de Derecho Mercantil, núms. 264-265, 2007, págs. 533 a 598. Sobre el subtransporte, PILOÑETA ALONSO, L. M., «El subtransporte: análisis crítico y teórico de un concepto práctico», Revista de Derecho Mercantil, núm. 262, 2006, págs. 1401 a 1438.

12 Sobre la conveniencia de adoptar un concepto expansivo de consumidor a los efectos de extender las normas de consumo a la generalidad de los viajeros, PILOÑETA ALONSO, L. M., «El contrato de transporte terrestre de personas: Fundamentos de su régimen jurídico, elementos y contenido», op. cit., págs. 884 a 886; GUILLÉN CARAMÉS, J., «Los derechos de los usuarios de transportes terrestres por carretera y ferrocarril», op. cit., págs. 58 a 61. 
cuando se haya hecho la advertencia de que está completo; d. Dificultar innecesariamente el paso en los lugares destinados al tránsito de personas; e. Llevar consigo cualquier animal, salvo que exista en el vehículo lugar destinado para su transporte, exceptuándose a los invidentes acompañados de perros, especialmente adiestrados como lazarillos; $\mathrm{f}$. Llevar materias u objetos peligrosos en condiciones distintas de las establecidas en la regulación específica sobre la materia; g. Desatender las instrucciones que, sobre el servicio, den el conductor o el encargado del vehículo), contemplándose la obligación del conductor y, en su caso, del encargado de los vehículos destinados a dicho servicio público de prohibir la entrada u ordenar su salida a los viajeros que las incumplan. Además, en cuanto al contenido concreto de las obligaciones y deberes de los viajeros hay que estar también a lo previsto en el contrato de transporte por el porteador así como a las normas que establecen los denominados requisitos de policía, que actualmente encontramos recogidos en los preceptos que regulan el régimen sancionador (art. 142.14 LOTT, para las infracciones de los viajeros; y 143.1.a para la sanción, prevista como multa de 100 a 200 euros, que será independiente de la posible obligación de indemnizar los daños y perjuicios causados).

Por otro lado, como destaca la Resolución del Parlamento Europeo de 23 de octubre de 2012, sobre los derechos de los pasajeros en todos los modos de transporte, los usuarios de los transportes no sólo tienen derechos sino también obligaciones, y cumplirlas contribuye a que todo funcione de manera segura y fluida, para ellos y otros pasajeros, antes, durante y después del viaje. El viajero, en este sentido, se halla obligado a respetar las condiciones y requisitos de policía establecidos para la buena marcha del servicio, como por ejemplo, la obligación de llevar fijado el cinturón de seguridad. Ha de observar un comportamiento acorde con el buen orden y no atentar contra la integridad del vehículo ni poner en riesgo la seguridad del transporte. En particular, se contempla como infracción leve el incumplimiento por los usuarios de las prohibiciones de impedir o forzar la apertura o cierre de las puertas de acceso a los vehículos o manipular los mecanismos de apertura o cierre; de hacer uso sin causa justificada de los mecanismos de seguridad o socorro para casos de emergencia; de abandonar el vehículo o acceder a éste fuera de las paradas establecidas, salvo causa justificada; de realizar, sin causa justificada, actos susceptibles de distraer la atención del conductor o entorpecer su labor cuando el vehículo se encuentre en marcha; de viajar en lugares distintos a los habilitados para los usuarios; o de realizar acciones injustificadas que puedan implicar deterioro o causar suciedad en los vehículos o estaciones de transporte ${ }^{13}$.

Como contraprestación a la obligación de traslado del porteador, la principal obligación del viajero es la de pagar el precio del transporte. Dicho pago se realizará personalmente cuando contratante principal y viajero coincidan; si el viajero es solo beneficiario, la obligación recae lógicamente sobre el contratante principal ${ }^{14}$. En cuanto al momento del

\footnotetext{
13 Más ampliamente, PILOÑETA ALONSO, L. M., «El contrato de transporte terrestre de personas: Fundamentos de su régimen jurídico, elementos y contenido», op. cit., págs. 935 a 938.

14 PILOÑETA ALONSO, L. M., «El contrato de transporte terrestre de personas: Fundamentos de su régimen jurídico, elementos y contenido», op. cit., págs. 883 a 886 y 932 a 935.
} 
pago, habrá que estar a lo establecido en el contrato; teniendo en cuenta que el billete constituye el título de legitimación habitual en los transportes regulares y que debe disponerse de él en los momentos iniciales del traslado y conservarse durante el mismo, coincidirá normalmente el momento del pago del precio con el de su expedición, y ello a pesar de la configuración jurídica de este contrato como de obra. Entre las infracciones leves contempladas en el artículo 142.14 LOTT se encuentra precisamente la de viajar careciendo de un título de transporte suficiente para amparar la utilización del servicio de que se trate.

En los servicios regulares de uso general, el régimen tarifario aplicable a los viajeros se incluye en el pliego de condiciones que rige el contrato de gestión del servicio público (art. 19 LOTT), donde se prevén sistemas de revisión, bien generales y periódicos (segundo trimestre de cada año) o bien individualizados, cuando se haya alterado significativamente, al alza o a la baja, el equilibrio económico del contrato. En los transportes regulares de uso especial o en los discrecionales, habrá que estar a lo dispuesto en el contrato suscrito entre el organizador y el porteador. Es de resaltar la libre fijación de precios por las partes contratantes en los transportes discrecionales de viajeros y en los transportes regulares de viajeros temporales o de uso especial (art. 18 LOTT).

Entre las obligaciones o deberes del usuario también se encuentran igualmente su presentación en el punto y tiempo establecido para la salida, como presupuesto previo del cumplimiento por parte del porteador de su obligación de traslado, la de ocupar la plaza asignada y la de abandonar el vehículo cuando llega a destino.

El viajero tiene la facultad de desistir del contrato de transporte tanto antes del viaje como una vez iniciado, pero habrá de indemnizar en su caso al porteador, abonándole los gastos en los que incurra y el lucro cesante.

\subsection{Obligaciones y responsabilidad del porteador}

Los supuestos de incumplimiento contractual que desatarán la responsabilidad del transportista por carretera de viajeros se hallan íntimamente conectados con las obligaciones esenciales que asume en virtud del contrato de transporte. Tales obligaciones consisten, fundamentalmente, en el traslado del viajero y su equipaje en las condiciones de seguridad, comodidad y en los tiempos pactados. Siguiendo el esquema clásico, los supuestos de incumplimiento pueden estructurarse en dos grandes grupos, los derivados del incumplimiento de la obligación de seguridad respecto al viajero y de la obligación de custodia respecto al equipaje facturado, de un lado; y los derivados de la falta de ejecución total o parcial del transporte, concretados en la cancelación, interrupción, retraso del viaje o daños derivados de enlaces perdidos, de otro. El incumplimiento de cualquiera de dichas obligaciones hace surgir también la obligación de asistencia al viajero, que igualmente será exigible en los supuestos de inimputabilidad del incumplimiento al porteador. 


\subsection{A. Las obligaciones del porteador}

El porteador se obliga, esencialmente, a poner a disposición del viajero el vehículo destinado al transporte y a admitirlo en él en orden a su transporte y el de su equipaje por el itinerario y en el plazo marcado, según las condiciones pactadas - ambiente, rapidez, comodidad... - y, por supuesto, incólume, y adoptando las medidas de seguridad necesarias, desde el acceso al vehículo, el traslado y la llegada al destino final; con dicha finalidad deberá el porteador procurar sistemas que cumplan las condiciones de seguridad necesarias para que la entrada y salida de los vehículos se efectúe de manera segura para el viajero, incluidos aquéllos que tengan movilidad reducida. A la obligación del traslado se une, por tanto, la obligación de protección del viajero, que es, por un lado, accesoria a la del traslado, pues se vinculan espacial y temporalmente, pero, por otro, autónoma de ella, pues tiene su propia finalidad y justificación, y de la misma se pueden derivar responsabilidades contractuales independientemente de la correcta ejecución de la obligación de traslado.

La obligación de protección del viajero se presenta como una obligación de resultado, a pesar de la movilidad que éste tiene durante el viaje, y no solo de medios ${ }^{15}$. Se trata también de una obligación compleja, pues comprende todas aquellas conductas que pudieran afectar a la seguridad del viajero, sin necesidad de que se encuentren tipificadas, como la de proveer un medio de transporte seguro y un espacio idóneo dentro del mismo, velar por la integridad del viajero, asegurando su incolumidad, adoptando para ello todas las medidas que resulten necesarias para garantizar su integridad física, incluyendo todas las cautelas que se requieran, así, como prestar un servicio de transporte adecuado ${ }^{16}$. Esta obligación de seguridad, y la consiguiente responsabilidad que pudiera derivarse de su incumplimiento, se extiende temporalmente no sólo al periodo en el cual el viajero está dentro del vehículo, sino también a la entrada y salida del mismo. En este ámbito, más allá de la clásica distinción entre responsabilidad objetiva o subjetiva en relación con el incumplimiento de esta obligación, emerge un nuevo concepto que es el de "la seguridad legítimamente esperable" del servicio de transporte, entendiendo que el porteador tiene la obligación de garantizar que el servicio no va a implicar riesgos que superen los

\footnotetext{
${ }^{15}$ En este sentido, en relación con el transporte marítimo, vid. MENÉNDEZ, A, «El contrato de pasaje marítimo», en AA.VV., Centenario de la Ley de Notariado, Vol. 4, Madrid, 1963, pág. 286; PACHECO CAÑETE, M., «Cuestiones de actualidad sobre la responsabilidad del transportista marítimo por daños a los pasajeros», Revista de Derecho del Transporte, núm. 9. ${ }^{\circ}$ (2012), págs. 97 y 98, quien afirma que «el reconocimiento junto a los deberes de prestación -cuál es la realización del transporte-, de los deberes de protección, fundamentados en la buena fe [...] nos lleva a afirmar la existencia de un deber de seguridad en el transporte de personas, con el consiguiente ensanchamiento de la responsabilidad contractual [...]. [L]a naturaleza de la obligación de seguridad como de medios o de resultado es una cuestión que reviste trascendencia práctica en orden a la prueba del incumplimiento del porteador que en otro caso resultaría excesivamente gravosa para el pasajero».

16 Vid. HUALDE MANSO, M ${ }^{\mathrm{a}} \mathrm{T}$., El transporte de viajeros por carretera: régimen de responsabilidad civil, Aranzadi Thomson Reuters, Pamplona, 1996, págs. 137 a 184. Referido también a otros medios de transporte, cfr. TULLIO, L, «La obligación de protección en el transporte marítimo y aéreo», Revista de Derecho del Transporte, núm. 11 (2013), págs. 14 y 19 a 20; OLMEDO PERALTA, E., Régimen jurídico del transporte marítimo de pasajeros. Contratos de pasaje y crucero, Marcial Pons, Madrid, 2014, págs. 235 a 239.
} 
esperables en condiciones normales ${ }^{17}$. El hecho de que se trate de una actividad organizada empresarialmente se vincula a un presupuesto previo que es la garantía implícita de seguridad, cercana al concepto legal de la diligencia exigible. Asumir un criterio objetivo y extremo de diligencia desemboca en una obligación de seguridad que opera con cierto automatismo, dado que la existencia de un daño que defraude las legítimas expectativas de seguridad del viajero hace saltar el resorte de la responsabilidad civil $^{18}$.

El patrón de diligencia exigible a los conductores se concreta en el artículo $3 .^{\circ}$ del citado RGC, que impone que deberán conducir con la diligencia y precaución necesarias para evitar todo daño, propio o ajeno, cuidando de no poner en peligro, tanto al mismo conductor como a los demás ocupantes del vehículo y al resto de los usuarios de la vía, quedando terminantemente prohibido conducir de modo negligente o temerario. Señalando, además, que las conductas referidas a la conducción negligente tendrán la consideración de infracciones graves y las referidas a la conducción temeraria tendrán la consideración de infracciones muy graves, de acuerdo con lo dispuesto respectivamente en los artículos 76.m y 77.e del Texto Refundido de la Ley sobre tráfico, circulación de vehículos a motor y seguridad vial, aprobado por R. D. Leg. 6/2015, de 30 de octubre. Adicionalmente, se contemplan entre otras prohibiciones la de transportar personas en emplazamiento distinto al destinado y acondicionado para ellas en los vehículos (art. 10.1 RGC) o la de que el número de personas transportadas en un vehículo sea superior al de las plazas que tenga autorizadas -que, en los de servicio público y en los autobuses, deberá estar señalado en placas colocadas en su interior, sin que, en ningún caso, pueda sobrepasarse, entre viajeros y equipaje, la masa máxima autorizada para el vehículo- (art. 9. ${ }^{\circ}$ RGC) y, específicamente para el transporte colectivo de personas, que el conductor deberá efectuar las paradas y arrancadas sin sacudidas ni movimientos bruscos, lo más cerca posible del borde derecho de la calzada, y se abstendrá de realizar acto alguno que le pueda distraer durante la marcha; finalmente, se señala que el conductor y, en su caso, el encargado, tanto durante la marcha como en las subidas y bajadas, habrán de velar por la seguridad de los viajeros (art. 11.1 RGC).

En la normativa comunitaria se incrementan, por otro lado, los deberes de información del porteador y de asistencia al viajero, particularmente en los supuestos de personas con discapacidad o movilidad reducida ${ }^{19}$. En efecto, el Reglamento (UE) núm. 181/2011, prevé la obligación del transportista de proporcionar, en caso de accidente resultante del

\footnotetext{
${ }^{17}$ Vid., por todos, PASQUAU LIAÑO, M., «El defecto de seguridad como criterio de imputación de responsabilidad al empresario de servicios», en AA.VV., La Responsabilidad Civil por Daños Causados por Servicios Defectuosos. Estudio de la responsabilidad civil por servicios susceptibles de provocar daños a la salud y seguridad de las personas, dir. por ORTI VALLEJO A. - GARCÍA GARNICA, M.C., coord. por ROJO ÁLVAREZ-MANZANEDA, R., Aranzadi Thomson Reuters, Pamplona, 2015, págs. 59 a 102.

${ }^{18}$ Cfr. JIMÉNEZ HORWITZ, M., «Los riesgos a cargo del perjudicado», en AA.VV., La Responsabilidad Civil por Daños Causados por Servicios Defectuosos..., op. cit., págs. 103, 107 a 108.

${ }^{19}$ Vid., en particular, Cap. III y anexo I Reglamento (UE) núm. 181/2011. Vid., asimismo, PILOÑETA ALONSO, L. M., «El contrato de transporte terrestre de personas: Fundamentos de su régimen jurídico, elementos y contenido», op. cit., págs. 924 a 930.
} 
uso del autobús o autocar, una asistencia adecuada y proporcionada a los viajeros para sus necesidades prácticas inmediatas tras el accidente (cuando resulte necesario, alojamiento -limitable su coste a 80 EUR por noche y viajero, por un máximo de dos noches -, comida, ropa, transporte y prestación de primeros auxilios, art. 8. ${ }^{\circ}$ ), así como otras medidas de asistencia en caso de cancelación o retraso en la salida (art. 21). La prestación de dicha asistencia se configura como un deber legal, por lo que no se vincula ni implica reconocimiento de responsabilidad por parte del porteador.

Asimismo, la norma europea establece disposiciones sobre la información mínima que debe ofrecerse a los viajeros. Tanto los transportistas como los gestores de las estaciones, dentro de sus respectivos ámbitos de competencia, han de suministrar a los viajeros la información general pertinente relativa al viaje y a las condiciones de transporte antes del viaje y durante el mismo, y siempre que sea posible, en formatos accesibles. El objeto de dicha información al viajero abarca desde los derechos que le asisten (art. 25 Reglamento núm.181/2011), a la información sobre las situaciones en caso de cancelación o retraso en la salida de un servicio regular, la pérdida de conexiones y sus alternativas (art. 20 Reglamento núm.181/2011).

En orden a facilitar que los viajeros puedan ejercer sus derechos de forma sencilla y ágil, se dispone sobre los transportistas la obligación de crear un mecanismo ágil de tramitación de reclamaciones, con plazos reducidos de respuesta (arts. 26 y 27 Reglamento núm.181/2011), sin perjuicio del derecho de los viajeros de solicitar ante los órganos jurisdiccionales nacionales indemnizaciones, de conformidad con el Derecho nacional, por los daños y perjuicios resultantes del fallecimiento, las lesiones, la cancelación o el retraso de los servicios regulares, entre otros supuestos de incumplimiento ${ }^{20}$.

Por su parte, el Reglamento (CE) núm. 1073/2009, del Parlamento Europeo y del Consejo, de 21 de octubre, por el que se establece normas comunes de acceso al mercado internacional de los servicios de autocares y autobuses, respecto a los servicios regulares internacionales que tengan lugar en territorio comunitario, dispone que el explotador de los mismos está obligado, salvo en los casos de fuerza mayor, a tomar las medidas que garanticen un servicio de transporte que cumpla las normas de continuidad, regularidad y capacidad, así como las demás condiciones fijadas por la autoridad competente; y a anunciar el itinerario del servicio, las paradas, el horario, las tarifas y las demás condiciones de transporte de modo que resulten fácilmente accesibles para todos los usuarios.

En relación con la contratación de seguros, además del seguro de responsabilidad civil de suscripción obligatoria previsto en el Texto Refundido de la Ley sobre responsabilidad civil y seguro en la circulación de vehículos a motor, aprobado por el R.D. Leg. 8/2004, de 29 de octubre (en adelante, TRLSCSVM) que, en su caso, ha de ser contratado por el

\footnotetext{
20 PILOÑETA ALONSO, L. M., «El contrato de transporte terrestre de personas: Fundamentos de su régimen jurídico, elementos y contenido», op. cit., págs. 930 a 932.
} 
propietario de los vehículos a motor que tengan su establecimiento habitual en España, las empresas de transporte público de viajeros por carretera han de suscribir el denominado seguro obligatorio de viajeros. Ambos seguros tienen la consideración de gasto de explotación y, por tanto, son repercutibles en las correspondientes tarifas (art. 21 LOTT). El seguro obligatorio de viajeros se regula por su Reglamento, aprobado por R.D. 1575/1989, de 22 de diciembre, alcanzando su protección a todos los usuarios de medios de transporte público colectivo español de viajeros, urbanos e interurbanos contemplados en la LOTT, en tanto circulen por territorio nacional y en todos los viajes que tengan su principio en dicho territorio, aunque sin limitación de destino ${ }^{21}$. Este seguro obligatorio tiene por finalidad indemnizar a los viajeros o a sus derechohabientes, cuando sufran daños corporales (muerte, invalidez permanente o incapacidad temporal del viajero) en accidente que tenga lugar con ocasión de desplazamiento en un medio de transporte público colectivo de personas, constituyendo una modalidad del seguro de accidentes individuales, compatible con cualquier otro seguro concertado por el viajero o referido a él. Finalmente, la contratación adicional de cualquier otro seguro de responsabilidad civil que cubra todos los daños que se causen con ocasión del transporte, de forma ilimitada o no, es potestad del porteador ${ }^{22}$, salvo en los casos especiales del transporte sanitario, en los términos previstos por el artículo 10.1.i y 25.g de la Orden PRE/1435/2013, de 23 de julio, por la que se desarrolla el Reglamento de la Ley de Ordenación de los Transportes Terrestres en materia de transporte sanitario por carretera $^{23}$, y en el del transporte escolar, según dispone el artículo 12 del Real Decreto 443/2001, de 27 de abril, sobre condiciones de seguridad en el transporte escolar y de menores ${ }^{24}$.

\subsection{B. La responsabilidad del porteador}

El principal tema planteado por el transporte de personas es, naturalmente, el de la disciplina de la responsabilidad del porteador en relación con los daños sufridos por la

\footnotetext{
${ }^{21}$ El Seguro Obligatorio de Viajeros fue implantado en España en 1929 como una medida más dentro de la política de desarrollo turístico. Se encuentra protegida por este seguro toda persona que en el momento del accidente esté provista del título de transporte, de pago o gratuito. Cuando el título de transporte se expida sin exigir la identificación del viajero, se presumirá que el accidentado estará provisto de billete en todos aquellos casos en que por las características del accidente sea verosímil el extravío o destrucción de dicho billete.

Vid., al respecto, ESTANCONA PÉREZ, A.A., op. cit., págs. 441 a 476; REGLERO CAMPOS, F., «Los seguros de responsabilidad civil y accidentes», en AA.VV., La Responsabilidad Civil por Daños Causados por Servicios Defectuosos..., op. cit., págs. 146 a 166.

${ }^{22}$ PILOÑETA ALONSO, L. M., «El contrato de transporte terrestre de personas: Fundamentos de su régimen jurídico, elementos y contenido», op. cit., págs. 918 a 924.

${ }^{23}$ En particular se exige que la empresa titular de una autorización de transporte público sanitario por carretera deberá tener cubierta su responsabilidad civil por los daños que se causen con ocasión del transporte, hasta, al menos, la cantidad de 50 millones de euros, circunstancia que se acreditará mediante el justificante de la suscripción del correspondiente seguro.

${ }^{24}$ En este caso, el aseguramiento exigido es ilimitado: "[Sin perjuicio del cumplimiento de la legislación vigente en materia de seguros obligatorios, las empresas que realicen cualquiera de los transportes incluidos en el artículo 1 deberán tener cubierta de forma ilimitada su responsabilidad civil por los daños que puedan sufrir los ocupantes de los vehículos en que aquéllos se realicen» (artículo 12).
} 
persona del viajero y los ocasionados en el equipaje, así como la responsabilidad del porteador por retraso en el transporte o la falta de ejecución total o parcial del mismo.

\subsection{B.a. Daños personales a los viajeros}

Los daños sufridos por el viajero en su persona en virtud del transporte constituyen un supuesto clásico de responsabilidad contractual. El transportista de personas se obliga contractualmente a llevarlas de un lugar a otro, pero se obliga a hacerlo de modo que lleguen indemnes a su destino.

La responsabilidad del porteador por daños personales al viajero se rige, más allá de lo dispuesto en los artículos 21 y 23 de la LOTT, por lo preceptuado en la legislación civil específica del contrato de obra (arts. 1.601 C.c. y ss.) y la general sobre el incumplimiento de los contratos (arts. 1.101 y ss. C.c.). No obstante, con ello no se agota el sistema, pues en materia de responsabilidad del porteador convergen distintos regímenes legales, que en ocasiones se solapan de forma cumulativa y, en otras, de forma subsidiaria, dada la especialidad y los límites indemnizatorios previstos en cada uno de ellos. Se expone a continuación el régimen general de responsabilidad del porteador así como los regímenes especiales cuya aplicación puede entrar en juego, interrelacionándolo, como no puede ser de otro modo, con las coberturas asegurativas que, bien con carácter obligatorio o voluntario, podemos encontrar en el ámbito del transporte de viajeros.

Además, hay que tener en cuenta que, cuando se trate de un transporte catalogado como servicio público, entran en juego las reglas de la responsabilidad patrimonial de las Administraciones Públicas. Los diferentes aspectos de dicha responsabilidad se regulan en los artículos 32 a 35 de la Ley 40/2015, de 1 de octubre, de Régimen Jurídico del Sector público. Se contempla el derecho de los particulares a ser indemnizados por las Administraciones Públicas correspondientes, de toda lesión que sufran en cualquiera de sus bienes y derechos, siempre que la lesión sea consecuencia del funcionamiento normal o anormal de los servicios públicos salvo en los casos de fuerza mayor o de daños que el particular tenga el deber jurídico de soportar de acuerdo con la Ley. Esta responsabilidad se configura como una responsabilidad directa, en tanto que la Administración no responderá subsidiariamente respecto al porteador, al margen de su derecho de repetición, y como una responsabilidad de presupuesto objetivo, ya que para que el daño concreto producido por el funcionamiento del servicio sea antijurídico, basta con que el riesgo inherente a su utilización haya rebasado los límites impuestos por los estándares de seguridad exigibles conforme a la conciencia social. La responsabilidad únicamente queda desvirtuada en casos de fuerza mayor o por ausencia de acreditación de la acción u omisión de la Administración y, en todo caso, por la culpa exclusiva de quien recibe el daño. Además, este régimen se aplica, tal y como señala el artículo 35 de la Ley 40/2015, también cuando las Administraciones actúen, directamente o a través de una entidad de derecho privado o en concurrencia con ésta, en relaciones de naturaleza privada, incluso cuando la responsabilidad se exija directamente a la entidad de derecho privado a través de la cual actúe la Administración o a la entidad aseguradora que cubra su 
responsabilidad ${ }^{25}$.

Régimen general.

Aunque existe un régimen especial para los daños derivados de la circulación de un vehículo a motor, que abarca también el ámbito de la responsabilidad extracontractual, y un régimen especial de responsabilidad por la prestación de servicios defectuosos relativos a medios de transporte (artículo 148 TRLGCU), la responsabilidad civil del porteador en virtud del contrato de transporte es más amplia, abarcando todos los daños que se causen con ocasión del transporte, aunque no sean derivados de los denominados hechos de la circulación (en los términos definidos por el RD 1507/2008, de 12 de septiembre, por el que se aprueba el Reglamento del seguro obligatorio de responsabilidad civil en la circulación de vehículos a motor $)^{26}$ o no estén sometidos al régimen especial de la legislación de consumo sobre servicios defectuosos. También resulta relevante invocar este régimen general de responsabilidad cuando los daños sufridos excedan los límites indemnizatorios establecidos en el citado régimen especial del TRLSCSVM y su correspondiente cobertura asegurativa máxima ${ }^{27}$.

Para que se derive esta responsabilidad contractual es necesario que, por acción u

${ }^{25}$ Vid., al respecto, más ampliamente, ESTANCONA PÉREZ, A.A., op. cit., págs. 120 a 129 y 205 a 215.
${ }^{26}$ Sobre el aspecto activo y pasivo del concepto circulación, sus limitaciones y exclusiones, vid. GARCÍA-
RIPOLL MONTIJANO, M., «El hecho de la circulación en la responsabilidad civil automovilística», en
AA.VV., Cuestiones clásicas y actuales del Derecho de daños: Estudios en Homenaje al Profesor Dr. Roca
Guillamón, coord. por ATAZ LÓPEZ, J. - COBACHO GÓMEZ, J.A., Aranzadi Thomson Reuters, Vol. 2 ,
2021 , págs. 873 a 968; BADILLO ARIAS, J.A., La conceptualización del hecho de la circulación en la
responsabilidad civil automovilistica y el seguro, Getafe, 2015, págs. 347 a 460, tesis doctoral en abierto
en archivo.uc3m.es/bitstream/handle/10016/21597/Jose_Bardillo_tesis.pdf?sequence=1\&isAllowed=y

${ }^{27}$ En este sentido, HUALDE MANSO, $\mathrm{M}^{\mathrm{a}} \mathrm{T}$., op. cit., pág. 149.

Otro planteamiento distinto defiende ROJO ÁLVAREZ-MANZANEDA, C., «La institución del seguro como sistema de protección al viajero por los daños personales causados en el contrato de transporte por carretera», en AA.VV., La nueva ordenación del mercado de transporte, dir. por RECALDE CASTELLS, A.- MARTÍNEZ SANZ, F. -PETIT LAVALL, M. ${ }^{2}$ V., coord. por PUETZ, A, Madrid, 2013, págs. 777 a 781, pues entiende que la responsabilidad civil contractual no puede quedar amparada por la cobertura ofrecida por el seguro de responsabilidad civil de la Ley de responsabilidad y seguro en la circulación de vehículos a motor al vincular su cobertura a los artículos 1.902 y siguientes del Código civil, y no a los artículos 1.101 y siguientes y 1.601 y siguientes del Código civil, distinguiendo por tanto entre la cobertura de las responsabilidades de origen contractual y las de origen extracontractual. Finalmente en la pág. 781, resuelve el problema de la compatibilidad de las indemnizaciones sobre la base de que el viajero en su condición de ocupante del vehículo está cubierto por el seguro obligatorio de la LRCSCVM, señalando que «si surgiese la obligación del transportista de indemnizar al viajero por los daños y perjuicios causados como consecuencia de habérsele considerado como civilmente responsable de forma extracontractual, será el seguro obligatorio de los vehículos a motor el que proceda a cubrir conforme al importe máximo de la cobertura del aseguramiento obligatorio la cantidad a la que pudiese resultar condenado, mientras que el resto hasta el montante total de la indemnización, sería dirigido con cargo al seguro voluntario o hacia el propio responsable del siniestro». No podemos compartir este posicionamiento pues el artículo $1 .^{\circ}$ LRCSCVM en relación a los daños a las personas no distingue entre responsabilidad civil contractual o extracontractual, abarcando ambas a los efectos de la cobertura del aseguramiento obligatorio. Tan solo respecto a los daños en los bienes, sí incorpora una distinción, refiriéndose exclusivamente al régimen de la responsabilidad civil extracontractual derivada de lo establecido en los artículos 1.902 y siguientes del Código Civil. 
o151uropeapropia o de sus dependientes o colaboradores, el porteador haya incumplido su obligación contractual. Dado que, a partir del incumplimiento, la culpa se presume en las obligaciones de resultado, la prueba de dicho incumplimiento exigiría tan solo la acreditación del daño a cargo del demandante, que tendrá que demostrar únicamente que el suceso que lo ocasionó ha ocurrido durante la ejecución del transporte y la realidad y el alcance del perjuicio sufrido ${ }^{28}$; ello conforme a las reglas que sobre la carga de la prueba se infieren del antiguo artículo 1.214 del Código Civil, actualmente recogidas en el artículo 217 de la Ley 1/2000, de 7 de enero, de Enjuiciamiento Civil ${ }^{29}$. En efecto, en las obligaciones de resultado se aplica la regla de la responsabilidad objetiva, de modo que la diligencia observada por el deudor para la atribución de la responsabilidad no tiene relevancia, porque la única cosa debida es el resultado, más allá de que pueda intervenir a efectos de modularla. Cuando, como ocurre en este supuesto, el sistema de responsabilidad propio atribuye a priori el riesgo a una de las partes, en este caso al empresario, las puntualizaciones se articulan a través de los hechos impeditivos de la

\footnotetext{
${ }^{28}$ Vid. LACRUZ BERDEJO, J.L., Elementos de Derecho Civil, T. II, Vol. 1. ${ }^{\circ}$, Barcelona, 1985, quien afirma que la culpa se presume en las obligaciones de resultado a partir del incumplimiento, mientras que en las obligaciones de medios no existe ninguna presunción a favor del acreedor que ha de probar que el deudor se comportó con negligencia o faltó a las reglas de la lex artis.
}

En efecto, el citado artículo 217 LEC atribuye al actor y al demandado reconviniente la carga de probar la certeza de los hechos de los que ordinariamente se desprenda, según las normas jurídicas a ellos aplicables, el efecto jurídico correspondiente a las pretensiones de la demanda y de la reconvención.

No obstante, la cuestión sobre si la distinción entre obligaciones de medios y de resultados sirve o no para la distribución de la carga de la prueba no es pacífica. En este sentido, JORDANO FRAGA, J., op. cit., afirma que el acreedor de una obligación de resultado que pretenda la responsabilidad contractual de su deudor, habrá de probar no sólo los daños que se hayan derivado de esa infracción, sino también la obligación que le une al deudor (el hecho o causa que la origina) y la infracción de tal obligación, su no cumplimiento o no exacto cumplimiento por parte del deudor; así también, ROJO ÁLVAREZMANZANEDA, C., «La institución del seguro como sistema de protección al viajero por los daños personales causados en el contrato de transporte por carretera», op. cit., pág. 773, quien afirma que «a pesar de la acreditación de la relación causal en este tipo de siniestros encierra particular dificultad porque la normalidad de su utilización implica ya un movimiento del vehículo que inevitablemente constituye una amenaza para la estabilidad del pasajero, es jurisprudencia constante que no basta con alegar la realización de un acto u omisión culpable, puesto que ni se presume la culpa del transportista ni tampoco se muestra laxitud en su apreciación, sino que el viajero debe dar la cumplida prueba del hecho generador del daño sufrido hasta el punto de que se considera que la acreditación de la culpa es un requisito básico para el éxito de la acción».

${ }^{29}$ En este sentido se pronunció la Sentencia del TS, Sala Primera, de 31 de mayo de 1985 (TOL1.736.558), cuyo considerando número 3 de sus Fundamentos de derecho resulta ilustrativo: "Considerando no discutida la existencia de un contrato de transporte terrestre de viajeros que vincula a las partes y surgiendo del mismo como obligación principal del porteador el traslado del pasajero desde el punto de partida al de destino, es manifiesto que el incumplimiento de tal deber, y las consecuencias dañosas para la vida o la integridad física del viajero que de tal incumplimiento se deriven, deben serle imputables en tanto no acredite que la falta de cumplimiento se debió a caso fortuito o fuerza mayor, y ello no sólo por tener declarado esta Sala que existe una presunción de culpabilidad en la falta de adecuación a lo pactado, (sentencias siete de abril de mil novecientos ochenta y tres), sino, también, porque la aplicación del principio del «onus probandi» proclamado en el artículo mil doscientos catorce del Código Civil lleva a la misma conclusión, pues si al actor corresponde probar los hechos normalmente constitutivos del derecho que reclama, cumple con tal carga demostrando la existencia del contrato de transporte del que surge la obligación de deudor, y si, éste invoca hechos impeditivos o extintivos tendrá que probarlos, por lo que alegado al caso fortuito como causa de incumplimiento a él corresponde la probanza de tal causa excluyente de la culpabilidad". 
responsabilidad o causas de exoneración. Por ello, en su caso, el porteador tendrá que probar la inimputabilidad del incumplimiento de su obligación de conducir sano y salvo al viajero, demostrando que los daños o lesiones sufridos por el viajero derivan de un evento calificable como caso fortuito o fuerza mayor (art. 1.105 Código civil). Claro está que el hecho de que lo «transportado» sean personas y, en consecuencia, seres cuya conducta durante el transporte no es totalmente controlable por el transportista, tiene influencia en esta materia. En concreto, cuando la conducta imprudente del viajero sea la causa única del accidente o infortunio, el porteador quedará eximido de responsabilidad. En estos términos se expresa el quinto párrafo del artículo 23 de la LOTT que, para el transporte de viajeros por carretera, dispone que «el transportista será responsable de cuantos perjuicios a los viajeros puedan derivarse de su incumplimiento de las obligaciones y formalidades prescritas por las leyes y reglamentos de las Administraciones Públicas, así como de las actuaciones que, como consecuencia de dicho incumplimiento pueda adoptar la Administración, en todo el curso del viaje y a su llegada al punto de destino, salvo que pruebe que dicho incumplimiento ha sido consecuencia de una actuación llevada a cabo sin su consentimiento por alguno de los usuarios o viajeros». Dado que dichas circunstancias nunca se presumen, han de ser alegadas y probadas por el porteador ${ }^{30}$. Como consecuencia de la aplicación de estas reglas sobre la carga de la prueba, resultará que el porteador no se liberará de responsabilidad cuando las causas que hayan provocado el accidente resulten indeterminadas, desconocidas o no puedan ser demostradas $^{31}$

Regímenes especiales: Responsabilidad civil por servicios defectuosos.

En cuanto a los regímenes especiales de responsabilidad reseñados, de un lado, ha de hacerse referencia al previsto, dentro del Libro del TRLGDCU dedicado a la responsabilidad civil por bienes o servicios defectuosos, en el artículo 148 TRLGCU, que impone específicamente a los prestadores de servicios relativos a medios de transporte la responsabilidad por los daños personales, incluida la muerte, y los daños materiales originados a los consumidores y usuarios en el correcto uso de los servicios, cuando por su propia naturaleza o por exigencias reglamentarias, incluyan necesariamente la garantía de niveles determinados de eficacia o seguridad, en condiciones objetivas de determinación, y supongan controles técnicos, profesionales o sistemáticos de calidad. Se trata ésta de una responsabilidad objetiva, a diferencia de la prevista para el régimen general en el artículo 147 TRLGDCU (subjetiva con inversión de la carga de la prueba), limitada no obstante a la cuantía de 3.005.060,52 euros. El hecho constitutivo de este régimen de responsabilidad estriba en la producción de un daño como consecuencia de la

\footnotetext{
${ }^{30}$ Vid. REGLERO CAMPOS, L.F. - PEÑA LÓPEZ, F., «El nexo causal. La pérdida de oportunidad. Las causas de exoneración de responsabilidad: culpa de la víctima y fuerza mayor», en AA.VV., Tratado de responsabilidad civil, coord. por REGLERO CAMPOS, L.F.- BUSTO LAGO, J.M., Aranzadi Thomson Reuters, Pamplona, 2014, págs. 767 a 970; ROMERO COLOMA, A.M., «Accidentes de tráfico: los supuestos de culpa exclusiva de la víctima, caso fortuito y fuerza mayor», Revista de Responsabilidad Civil, Circulación y Seguro, núm. 10, 1998, págs. 528 a 533.

${ }^{31}$ Cfr. HUALDE MANSO, Ma T., op. cit., pág. 158.
} 
prestación del servicio causado por una desviación respecto de los estándares de seguridad razonablemente esperables (art. 11 TRLGDCU) ${ }^{32}$. Aun cuando el precepto nada indica al respecto, el límite máximo de indemnizatorio ha de relacionarse con la responsabilidad del porteador derivada de un mismo suceso, y no operaría como límite de la indemnización individual de cada perjudicado, teniendo en cuenta que dichos daños son resarcibles acumulativamente a través de otras vías, como a continuación se expondrá ${ }^{33}$.

En efecto, la indemnización contemplada en el artículo 148 TRLGDCU es compatible con otros derechos que el perjudicado pueda tener a ser indemnizado por daños y perjuicios, incluidos los morales, como consecuencia de la responsabilidad contractual, fundada en la falta de conformidad de los servicios o en cualquier otra causa de incumplimiento o cumplimiento defectuoso del contrato, o de la responsabilidad extracontractual, tal y como reconoce expresamente el artículo $128 \mathrm{TRLGDCU}^{34}$. Por tanto, este régimen especial de responsabilidad civil por daños al consumidor no excluye el de la responsabilidad civil general o la derivada de otros regímenes especiales.

Regímenes especiales: Responsabilidad civil derivada de la circulación de un vehículo a motor.

De otro lado, refiriéndonos ya al segundo de los regímenes especiales de responsabilidad, para delimitar el alcance de la responsabilidad civil derivada de la circulación de un vehículo a motor, independientemente del origen contractual o extracontractual de la obligación, hay que atender a lo dispuesto en el TRLSCSVM y en su Reglamento de desarrollo. El artículo 1. ${ }^{\circ}$ TRLSCSVM, bajo el esquema de una responsabilidad cuasi objetiva en virtud del riesgo creado, atribuye al conductor la responsabilidad por los daños causados a las personas o en los bienes con motivo de la circulación del vehículo. Se trata de una responsabilidad por hechos propios fundamentada en la llamada culpa in operando, que se complementa, en el caso de omisión de la actividad obligatoria o razonablemente esperada, con la llamada culpa in omittendo. Dicha responsabilidad es exigible también a la persona no conductora, cuando esté vinculado con ésta por alguna de las relaciones que regula el artículo 1.903 del Código Civil, referido a la responsabilidad por hechos ajenos; destaca en el ámbito del transporte de personas, la de los dueños o directores de un establecimiento o empresa respecto de los perjuicios

\footnotetext{
${ }^{32}$ Cfr. PASQUAU LIAÑO, M., op. cit., pág. 84. Vid, además, específicamente, EstANCONA PÉREZ, A.A., op. cit., págs. 215 a 222.

${ }^{33}$ En contra, no obstante, PARRA LUCÁN, M. a, «Daños causados por otros bienes o servicios», en AA.VV., Comentario del Texto Refundido de la Ley General para la Defensa de los Consumidores y Usuarios y otras leyes complementarias (Real Decreto Legislativo 1/2007), coord. por BERCOVITZ

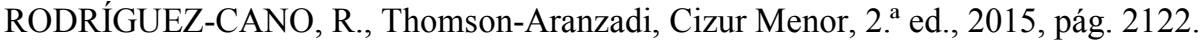

34 PARRA LUCÁN, M. , «Responsabilidad civil por bienes o servicios defectuosos», en AA.VV., Comentario del Texto Refundido de la Ley General para la Defensa de los Consumidores y Usuarios y otras leyes complementarias (Real Decreto Legislativo 1/2007), op. cit., págs. 1843 a 1928; y, particularmente, en la misma obra, «Capítulo II. Daños causados por otros bienes y servicios», págs. 2116 a 2122 .
} 
causados por sus dependientes en el servicio de los ramos en que los tuvieran empleados, o con ocasión de sus funciones; esta responsabilidad cesará cuando la persona pruebe que empleó toda la diligencia de un buen padre de familia para prevenir el daño ${ }^{35}$. Por otro lado, el propietario no conductor de un vehículo que circule sin la cobertura vigente de un seguro de suscripción obligatoria responderá civilmente con el conductor del mismo de los daños a las personas y en los bienes ocasionados por éste, salvo que pruebe que el vehículo le hubiera sido sustraído. Finalmente, en el ámbito penal, el artículo 120.5 del Código Penal declara la responsabilidad civil subsidiaria de los que lo sean criminalmente, de las personas naturales o jurídicas titulares de vehículos susceptibles de crear riesgos para terceros, por los delitos cometidos en la utilización de aquellos por sus dependientes o representantes o personas autorizadas.

En esta materia, también hay que tener en cuenta, en el ámbito del seguro obligatorio de responsabilidad civil, la facultad de repetición de las aseguradoras, una vez efectuado el pago de la indemnización a la víctima o sus causahabientes, para la recuperación de las sumas abonadas, contra el conductor, el propietario del vehículo causante y el asegurado, si el daño causado fuera debido a la conducta dolosa de cualquiera de ellos o a la conducción bajo la influencia de bebidas alcohólicas o de drogas tóxicas, estupefacientes o sustancias psicotrópicas. Esta medida, prevista en el artículo 10 TRLSCSVM, compatibiliza el principio de inasegurabilidad del propio dolo con la protección del tercero perjudicado. Ahora bien, el derecho de repetición frente al propietario del vehículo y el asegurado no conductores no tendrá lugar cuando el accidente se haya producido habiendo sido el vehículo objeto de hurto o hurto de uso y, desde luego, es cuestionable la repetición cuando no pueda imputarse la acción dolosa o negligente al propietario ni al asegurado, debiendo proceder únicamente en su caso cuando el estado de embriaguez les sea imputable o cuando hubieran permitido la circulación conociendo el estado del conductor.

Una vez probado el incumplimiento, es preciso valorar su imputabilidad al porteador, en

\footnotetext{
${ }^{35}$ Efectivamente, el patrón general de diligencia previsto en nuestro ordenamiento es el del buen padre de familia (artículo 1.104 Código civil), que se identifica en el ámbito mercantil con el buen profesional o el ordenado comerciante. El término ordenado, empleado en las leyes especiales mercantiles para referirse al deudor comerciante o empresario, implica una superior diligencia, exigible a los empresarios como deudores de carácter cualificado por dedicarse de forma típica y habitual a una actividad. Existen por tanto dos modelos objetivos de referencia (el estándar del buen padre de familia y el estándar del ordenado empresario) o de dos tipos de diligencia específicos, el general y el profesional o empresarial. El tipo de diligencia exigible a los profesionales, en tanto poseedores de unos conocimientos especiales y unas determinadas técnicas (lex artis), debe ser distinto del exigible al deudor común (vid., por todos, RAMOS HERRANZ, I., «El estándar mercantil de diligencia: El ordenado empresario», Anuario de Derecho Civil, núm. LIX-1, Enero 2006, págs. 195 a 225). Trasladándolo al ámbito que nos ocupa, el patrón de diligencia exigible será el de un ordenado transportista, lo cual significa que deberá observar los principios técnicos que rigen su profesión, exigiéndosele una pericia normal media de un profesional del transporte terrestre o diligencia razonable en el sector. Este concepto de la diligencia razonable es lo suficientemente amplio y flexible como para permitir que en la valoración del comportamiento del porteador sean tomadas en consideración las circunstancias del caso en concreto así como el coste económico de las medidas que debieron ser adoptadas para impedirlo, o, en su caso, para reducir el alcance de las consecuencias. Además, hay que tener en cuenta, respecto al conductor, el patrón de diligencia exigible concretado en el artículo $3 .^{\circ}$ del RGC (expuesto supra).
} 
atención a las causas exoneratorias. En cuanto a la exoneración de responsabilidad en el caso de daños a las personas, contempla el citado artículo 1. ${ }^{\circ} 1$ TRLSCSVM que sólo quedará exonerado el conductor cuando pruebe que los daños fueron debidos únicamente a la culpa exclusiva del perjudicado o a fuerza mayor extraña a la conducción o al funcionamiento del vehículo; no considerándose casos de fuerza mayor los defectos del vehículo ni la rotura o fallo de alguna de sus piezas o mecanismos. El esfuerzo probatorio, imprescindible para desvirtuar la responsabilidad del porteador, recae sobre éste. Para exonerarse de responsabilidad, tendrá que demostrar no solo que los daños fueron causados por circunstancias exteriores concretas (por ejemplo, un accidente causado por una catástrofe natural) o por causa de terceros o del propio viajero, probando el hecho extintivo de su responsabilidad y la relación de causalidad entre éste y el daño sufrido, sino también que obró con la diligencia debida. La inevitabilidad abarca tanto la producción del hecho como sus consecuencias, lo cual nos lleva de nuevo a la necesidad de valorar la conducta del porteador en orden a evitar las consecuencias dañosas y al parámetro de comportamiento esperable de un diligente y ordenado profesional del transporte rodado ${ }^{36}$.

La constatación de una causa de exoneración de la responsabilidad del porteador es indiferente desde el punto de vista de la actuación a la que está obligado para superar dicha circunstancia o mitigar los daños que pueden derivarse de la misma. Subsiste en todo caso la obligación de protección del viajero y asistencia a las víctimas.

Otro supuesto distinto se presenta cuando la víctima contribuye a la producción del daño ${ }^{37}$, en cuyo caso se reducirán todas las indemnizaciones, incluidas las relativas a los gastos en que se haya incurrido en los supuestos de muerte, secuelas y lesiones temporales, en atención a la culpa concurrente hasta un máximo del $75 \%$. Se articula así un sistema de responsabilidad supra objetiva en atención a que se establece un límite mínimo de culpa imputable al causante del daño, que permitirá en todo caso a la víctima cobrar, al menos, un $25 \%$ de la indemnización ${ }^{38}$. Se entiende que existe dicha contribución si la víctima, por falta de uso o por uso inadecuado de cinturones, casco u otros elementos protectores, incumple la normativa de seguridad y provoca la agravación

\footnotetext{
${ }^{36}$ Cfr. DÍAZ MORENO, A., «El contrato de transporte terrestre nacional de mercancías», en AA.VV., Derecho Mercantil, cit., pág. 295.

${ }^{37}$ Sobre la concurrencia de culpas, vid. SOTO NIETO, F., «La llamada compensación de culpas», Revista de Derecho Privado, núm. 52, 1968, págs. 409 a 427; DÍEZ-PICAZO, L., Derecho de daños, Civitas, Madrid, 1999, págs. 366 y 367; MONTERROSO CASADO, E., Responsabilidad por Accidentes de Circulación. La Concurrencia de Causas, Aranzadi, Navarra, 2009; MONTÉS PENADÉS, V.L., «Casualidad, imputación objetiva y culpa en la "concurrencia de culpas"», en AA.VV., Estudios jurídicos en homenaje al profesor Luis Diez-Picazo, coord. por CABANILLAS SÁNCHEZ, A., Civitas, Madrid, Vol. 2, 2002, págs. 2591 a 2628; MARTÍN-CASALS M., «A través del espejo: concurrencia de "culpa" de la víctima y culpa del causante del daño», en AA.VV., Estudios jurídicos en homenaje al profesor Luis Díez-Picazo, op. cit., págs. 2471 a 2490.

38 Vid. HERNÁNDEZ BAREA, H., «Concurrencia de culpas: moderación de indemnizaciones», Cuadernos de derecho judicial, Ejemplar dedicado a Derecho de seguros, III, dir. por ARROYO FIESTAS, F.J., nº 12, 1997, págs. 109 a 238; MAGRO SERVET, V., «Moderación de la indemnización en accidentes de tráfico por concurrencia de la culpa de la víctima o perjudicado», Tráfico y seguridad vial, núm. 89, 2006, págs. 5 a 14.
} 
del daño. En los supuestos de secuelas y lesiones temporales, la culpa exclusiva o concurrente de víctimas no conductoras de vehículos a motor que sean menores de catorce años o que sufran un menoscabo físico, intelectual, sensorial u orgánico que les prive de capacidad de culpa civil, no suprime ni reduce la indemnización y se excluye la acción de repetición contra los padres, tutores y demás personas físicas que, en su caso, deban responder por ellas legalmente. No obstante, tales reglas no procederán si el menor o alguna de las personas mencionadas han contribuido dolosamente a la producción del daño.

Finalmente con los mismos límites expuestos, se procederá a la reducción proporcional de la indemnización en caso de que la víctima incumpla su deber de mitigar el daño, esto es, lleve a cabo una conducta generalmente exigible que, sin comportar riesgo alguno para su salud o integridad física, habría evitado la agravación del daño producido y, en especial, si abandona de modo injustificado el proceso curativo.

Los daños y perjuicios causados a las personas, comprensivos del valor de la pérdida sufrida y de la ganancia que hayan dejado de obtener, previstos, previsibles o que conocidamente se deriven del hecho generador, incluyendo los daños morales, se cuantifican en todo caso con arreglo a los criterios y dentro de los límites indemnizatorios fijados en un anexo que acompaña a la norma, el conocido como Baremo de tráfico. Dicho baremo ha sido completamente actualizado por la Ley 35/2015, de 22 de septiembre, de reforma del sistema para la valoración de los daños y perjuicios causados a las personas en accidentes de circulación. Se trata de la única herramienta de carácter objetivo y detallado que, hasta la fecha, existe en nuestro país para que los distintos agentes implicados en cualquier suceso puedan valorar en términos económicos los daños, tanto personales -incluidos los morales- como patrimoniales ${ }^{39}$. El baremo vertebra y estructura el quantum indemnizatorio por conceptos, facilitando no solo la labor de los jueces, sino también la de las víctimas, en orden a acreditar el daño y valorarlo. El sistema se inspira

\footnotetext{
${ }^{39}$ Vid., al respecto, HERNÁNDEZ CUETO, C., «El uso de baremos en la valoración de daños personales. La reforma del baremo de tráfico», Cuadernos médicos forense, Vol. 20, núm. 4, 2014, http://scielo.isciii.es/scielo.php?script=sci_arttext\&pid=S1135-76062014000300001, quien destaca que la cuantificación y la indemnización de daños personales debe apoyarse en el empleo de baremos, destacando las numerosas ventajas de su utilización: «a) Facilita la comprensión del informe pericial para el no iniciado. Transformar la compleja red de secuelas que un paciente puede presentar, sus consecuencias, interacciones y evoluciones futuras, en una cifra, o en varias combinadas, situadas dentro de una escala concreta (siendo la más frecuente de 0 a 100), permite al lector obtener de inmediato y con suma facilidad una imagen resumen bastante cercana a la realidad sobre la situación del paciente y sus posibles consecuencias, del verdadero quantum que el experto pretende analizar y expresar en su informe; b) Introduce un elemento común que uniformiza los criterios de cuantificación, aproximando los casos de valoración a lo más cercano posible al concepto de Justicia, de tal modo que casos similares sean tratados de igual forma; c) Facilita los acuerdos amistosos fuera de la vía judicial, descargando considerablemente el trabajo de la Administración de Justicia, acelerando el acceso de la víctima a la compensación económica y la atención de otras necesidades perentorias en los casos más graves, como la atención especializada continuada, la adaptación del domicilio y la eliminación de barreras arquitectónicas, la adecuación del transporte personal mediante la adquisición de un vehículo adaptado, y un largo etcétera; d) Permite a mutuas y compañías aseguradoras hacer previsiones económicas precisas y esenciales para el adecuado futuro funcionamiento de estas entidades esenciales en el sistema nacional que permite la compensación de daños en nuestro país»; HOLGADO, J., «El nuevo baremo les vuelve locos», Capital Madrid, 15 de julio de 2014, https://www.capitalmadrid.com/2014/7/15/34532/el-nuevo-baremo-les-vuelve-locos.html;
} 
en el principio de reparación íntegra del daño corporal; su finalidad es la de lograr la total indemnización de los daños y perjuicios padecidos para situar a la víctima o a los perjudicados en una posición lo más cercana posible a la que tendrían de no haberse producido el accidente. Por otro lado, identifica nuevos perjudicados y nuevos conceptos resarcitorios, sistematizando y dotando de sustantividad propia las indemnizaciones por daño patrimonial (daño emergente y lucro cesante). Destaca también el significativo aumento del conjunto de las indemnizaciones, en particular las que corresponden a los casos de fallecimiento $-\mathrm{y}$, en especial, la de los hijos de víctimas fallecidas- $\mathrm{y}$ de grandes lesionados, proporcionando una mayor justicia resarcitoria. En efecto, el baremo distingue, a dichos efectos, entre tres niveles de individualización perjudicial, separando los perjuicios básicos, de los perjuicios particulares y de los perjuicios excepcionales; por otro lado, establece una serie de categorías de perjudicados, cuyo resarcimiento entre sí es compatible, al eliminarse la asignación de indemnizaciones por grupos consecutivos excluyentes, en atención a la doctrina del perjuicio propio de los familiares del fallecido; y consagra legalmente el principio de la doble presunción, determinante de que se presuma que quienes figuran catalogados como perjudicados vean reconocida su condición perjudicial, salvo prueba en contrario; y que quienes no están catalogados no gocen de la condición perjudicial, pero igualmente salvo prueba en contrario ${ }^{40}$. La cuantía de la indemnización cubierta por el seguro obligatorio en los daños causados a las personas se determinará atendiendo a ello, pero si la cuantía de las indemnizaciones resultase superior al importe de la cobertura del seguro obligatorio (70 millones de euros por siniestro, cualquiera que sea el número de víctimas), se satisfará, con cargo a éste, dicho importe máximo, y el resto hasta el montante total de la indemnización quedará a cargo del seguro voluntario o del responsable del siniestro, según proceda, en los términos del régimen general de responsabilidad expuesto supra. En el caso de daños en los bienes, el conductor responderá frente a terceros cuando resulte civilmente responsable según lo establecido en los artículos 1.902 y siguientes del Código civil, artículos 109 y siguientes del Código Penal (en este caso, el límite de la cobertura del seguro obligatorio alcanza los 15 millones de euros por siniestro).

Regímenes especiales: Responsabilidad civil en los transportes en autocar y autobús regulados por el Reglamento (UE) núm. 181/2011

Para los transportes en autocar y autobús que entran dentro del ámbito de aplicación del Reglamento (UE) núm. 181/2011—recuérdese, en este caso, transportes con embarque o desembarque dentro de la Unión Europea, tanto discrecionales como los regulares cuya distancia programada sea igual o superior a $250 \mathrm{~km}$-, no se establece una limitación de responsabilidad del porteador similar a la que contemplan los reglamentos referidos a los medios de transporte marítimo y aéreo, sino que la norma europea se remite a los derechos nacionales del viajero, en consonancia, por otro lado, con el reglamento europeo en el ámbito de transporte ferroviario de viajeros [Reglamento (CE) núm. 1371/2007 del

\footnotetext{
${ }^{40}$ Cfr. MEDINA CRESPO, M., El resarcimiento de los perjuicios personales causados por la muerte en el nuevo Baremo de Tráfico, Madrid, 2015.
} 
Parlamento Europeo y del Consejo, de 23 de octubre de 2007, sobre los derechos y las obligaciones de los viajeros de ferrocarril $]^{41}$. En efecto, los viajeros o causahabientes tendrán derecho a una indemnización por fallecimiento o lesiones corporales como consecuencia de accidentes resultantes del uso del autobús o autocar, que se calculará de conformidad con su derecho nacional, teniendo en cuenta que el límite máximo establecido por los derechos nacionales respectivos no podrá será inferior a 220.000 euros por viajero [art. 7. ${ }^{\circ}$ Reglamento (UE) núm. 181/2011].

$\mathrm{Al}$ respecto, en nuestro ordenamiento nacional hay que tener en cuenta lo dispuesto en el artículo 21 LOTT que, mezclando responsabilidad civil y aseguramiento de la misma y, cuestionablemente, seguro obligatorio de viajeros, establece que «en los transportes en autobús y autocar, el transportista responderá de las obligaciones establecidas frente a los viajeros, en los términos previstos en el Reglamento (UE) núm. 181/2011 [...], en la medida en que éstas no estén cubiertas íntegramente por el seguro obligatorio de viajeros, por el seguro de responsabilidad civil de suscripción obligatoria previsto en el texto refundido de la ley sobre responsabilidad civil y seguro en la circulación de vehículos a motor, aprobado por por el Real Decreto Legislativo 8/2004, de 29 de octubre, o por cualquier otro seguro».

El mencionado Seguro Obligatorio de Viajeros constituye efectivamente una modalidad de seguro de accidentes individuales, que debe ser compatible con cualquier otro seguro concertado por el viajero o referente a él. Por ello, no libera a las empresas transportistas o a los terceros de la responsabilidad civil en que pudieran incurrir por razón del transporte de personas, ni las prestaciones satisfechas con cargo a este seguro reducen el importe de dicha responsabilidad (artículo 2. ${ }^{\circ} 3$ RD 1575/1989) ${ }^{42}$. En el mismo sentido se

\footnotetext{
${ }^{41}$ Llama la atención, además, la diferencia cuantitativa respecto al límite máximo de la responsabilidad del porteador en otros medios de transporte (respecto al transporte marítimo, el Reglamento (CE) núm. 392/2009, del Parlamento Europeo y del Consejo, de 23 de abril de 2009, sobre la responsabilidad de los transportistas de pasajeros por mar en caso de accidente contempla una responsabilidad máxima de 400.000 unidades de cuenta y respecto al transporte aéreo, la responsabilidad puede llegar a ser ilimitada, en virtud de lo dispuesto en el Reglamento (CE) núm. 2027/1997, del Consejo, de 9 de octubre, sobre responsabilidad de las compañias aéreas en caso de accidente.

42 En este sentido, señala la Sentencia del Tribunal Supremo 627/2011, de 19 de septiembre (TOL2.245.397), que «[L] as obligaciones del asegurador, nacidas del seguro de viajeros, son indisponibles, y no pueden quedar sujetas ni a la voluntad del propio asegurador ni a la de terceros, ni a la determinación de la responsabilidad por el siniestro. Una interpretación favorable a la compatibilidad de ambas indemnizaciones es la única que garantiza la seguridad jurídica que exige el artículo $51 \mathrm{CE}$, y los derechos de los consumidores y usuarios contemplados en los artículos 7 y 11 de la anterior ley y 19 y 21 del actual Texto Refundido.

A esta conclusión se llega teniendo en cuenta que, en una interpretación como la efectuada por la AP, contraria a la compatibilidad de ambas indemnizaciones, se obliga al usuario del transporte a decidir, de manera previa, si existe responsabilidad civil del conductor, concurrencia de culpas o incluso exención de responsabilidad, cuando esta solo queda determinada tras una resolución judicial. Y todo ello, a pesar de tener un seguro de accidentes que no depende de quien haya resultado culpable del siniestro.
}

Se impone al usuario la obligación de decidir entre una y otra indemnización, o la de pedirlas de forma subsidiaria, poniéndole en grave riesgo de pago de las costas procesales, o en el mejor de los casos, en la imposibilidad de recobrar las suyas. Además, se imputa al usuario, que paga el billete y la prima del SOV, el pago de una prima de un seguro que va a resultar inefectivo en caso de responsabilidad civil declarada. 
expresa el artículo 5. ${ }^{\circ}$ del ROTT que prevé que los viajeros que se desplacen en transportes públicos por carretera, por ferrocarril o por cable deberán estar cubiertos por el seguro obligatorio de viajeros regulado por RD 1575/1989, contemplando también, adicionalmente, la obligación de las empresas prestadoras de los referidos servicios de transporte de tener cubierta su responsabilidad civil por los daños que causen con ocasión del transporte. En definitiva, las indemnizaciones derivadas de ambos seguros deben ser compatibles y acumulables entre sí $^{43}$, porque no estamos ante un supuesto de seguro doble o cumulativo ni podemos reconducir el concepto de enriquecimiento injusto, propio de los seguros de daños, a un seguro de personas, como es el seguro obligatorio de viajeros ${ }^{44}$. Los intereses asegurables son distintos: uno cubre el patrimonio del porteador, en cuyo seno puede nacer una deuda de responsabilidad civil (se trata de un seguro de daños y, en consecuencia, queda sometido al principio indemnizatorio del artículo 26 de la Ley 50/1980, de 8 de octubre, de Contrato de Seguro, en adelante, LCS), y otro el ser humano (tratándose de un seguro de personas, donde no hay correlación entre valor real del interés expuesto al riesgo y la suma asegurada, cuya virtualidad se circunscribe a la determinación de la indemnización a percibir y la prima correspondiente). Por ello, además, encontramos las lógicas diferencias también en materia de subrogación del asegurador frente al responsable del daño, recurso éste que es posible en el seguro de responsabilidad civil en su condición de seguro de daños (artículo 43 LCS) y, en ningún caso, en el seguro de accidentes en su condición de seguro de personas (artículo 82 LCS, exceptuando los gastos de asistencia sanitaria). Ambos seguros no guardan jurídicamente relación alguna, más allá del dato fáctico de que el mismo hecho pueda, en su caso, determinar o desencadenar el acaecimiento del siniestro en los dos contratos ${ }^{45}$. El seguro

Es por todo lo anterior que se considera más acertada la postura defendida por la doctrina minoritaria, sobre la compatibilidad de ambas indemnizaciones».

${ }^{43}$ En contra, no obstante, en un primer momento ROJO ÁLVAREZ-MANZANEDA, C., «Transporte Terrestre», en AA.VV., La Responsabilidad Civil por Daños Causados por Servicios Defectuosos..., op. cit., pág. 395. Posteriormente aboga por la compatibilidad de ambos seguros en «La institución del seguro como sistema de protección al viajero por los daños personales causados en el contrato de transporte por carretera», en AA.VV., La nueva ordenación del mercado de transporte, coord. por PUETZ, A. y dir. por PETIT LAVALL, M.V., MARTÍNEZ SANZ, F. - RECALDE CASTELLS, A.J., Marcial Pons, Madrid, 2013, págs. 786 a 788. Estudia pormenorizadamente la compatibilidad del seguro obligatorio de viajeros con otros seguros, ESTANCONA PÉREZ, A.A., op. cit., págs. 470 a 476, manifestándose también en contra al afirmar que «la indemnización total, de ambos seguros, no superará el valor real del daño efectivamente causado, descartando así el supuesto enriquecimiento injusto que pudiera causar una doble indemnización». Igualmente afirma que «no habrá duplicidad indemnizatoria porque el perjudicado no recibirá dos indemnizaciones».

${ }^{44}$ En este sentido, resulta muy ilustrativa la citada Sentencia del Tribunal Supremo 627/2011, de 19 de septiembre (TOL2.245.397), donde puede leerse sobre el seguro obligatorio de viajeros que «por su naturaleza de seguro de personas, un seguro en el que el derecho del perjudicado a ser indemnizado por el daño personal sufrido deriva de la simple concurrencia del hecho objetivo del accidente, al margen de la posible culpa del conductor del vehículo en que viaja, que además, como seguro de suma, tampoco se encuentra sujeto a la exigencia de indemnización concreta del daño, ni a la prohibición de enriquecimiento injusto del artículo 26 LCS, ni a las reglas que rigen el abono de la indemnización en caso de seguro múltiple (art. 32 LCS), resultando compatibles en el ámbito de los seguros de personas el aseguramiento múltiple y cumulativo del mismo riesgo»».

${ }^{45}$ La cuestión de la compatibilidad de los seguros y la acumulación de las indemnizaciones ha sido muy controvertida en los tribunales. A favor de la acumulación de indemnizaciones se pronuncia la Audiencia Provincial de Asturias (Sección 5. a) en su Sentencia núm. 97/2009, de 18 marzo (AC 2009\515), cuyo 
fundamento jurídico $2 .^{\circ}$ hace un exhaustivo recorrido por las distintas posiciones jurisprudenciales: «...la parte apelante sostiene que debe declararse procedente la indemnización reclamada con cargo al seguro obligatorio de viajeros, y ello por resultar compatible con la reclamada en base al seguro derivado de la LRCSCVM.

Esta cuestión, controvertida desde luego, ha sido objeto de estudio por este Tribunal, entre otras en la sentencia que cita la recurrente de 23-4-08 (JUR 2008, 318012), y que reitera otra posterior de 26-10-08, en la que afirmó en su fundamento tercero lo siguiente: "El siguiente motivo relativo a la compatibilidad de la indemnizaciones derivadas de uno y otro seguro, debe asimismo rechazarse, pues es criterio reiterado de esta Sala, entre otras en sus sentencias de 10-6-99 (AC 1999, 6057), 28-9-2004 (JUR 2004, 277435) y 27-11-2006 (JUR 2007, 23554), el de su compatibilidad.

De acuerdo con el criterio del recurrente, después de la Reforma introducida en el artículo 21 de la LOTT por la Ley 14/2000 de 29 de diciembre, no puede duplicarse la indemnización y satisfacerse por razón del Seguro obligatorio de viajeros aquel daño que ya se haya contemplado y resarcido por el seguro de la LRCSCVM.

Ciertamente ese es el criterio abrumadoramente mayoritario entre los tribunales de nuestras Audiencias, esto es, el de la compatibilidad de uno y otro seguro, pero no la acumulación o duplicidad de las indemnizaciones si el daño resarcible es el mismo, debiendo primar, en tal caso, la aplicación del régimen resarcitorio previsto en la LRSCVM, y en este sentido y dirección se han pronunciado las SSAP de

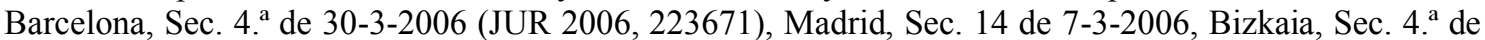
17-2-2006 (JUR 2006, 156787), León Sec. 2. ${ }^{a}$ de 2-2-2006, Ourense Sec. 2. ${ }^{\text {a }}$ de 30-12-2004 (JUR 2005, 43645), Córdoba Sec. 1. a de 25-11-2004 o Huelva Sec. 1. a de 19-12-2006 y la Secc. 6. ${ }^{\text {a }}$ de esta Audiencia en sus resoluciones de 12-2-2007 (JUR 2007, 245084), 26-3-2007 (JUR 2007, 213720) y 26-7-2007 (JUR 2007, 355812) ); mientras es minoritario el criterio contrario sostenido, entre otras, por las SSAP de Almería Sec. 3. ${ }^{a}$ de 14-6-2004 (AC 2004, 1475) y Córdoba Sec. 7. ${ }^{\text {de }}$ de 1-7-2001 (AC 2001, 1714), al que se suma, como ya dijimos, esta Sección de la AP de Asturias.

Sin perjuicio de otras, puede tomarse como referente del pensamiento mayoritario la sentencia citada de la AP de Cáceres de 14-12-2006, de acuerdo con la cual la modificación introducida por la Ley 14/2000 de 29 de diciembre de la LOTT 16/1987 de 30 de julio aboca a la incompatibilidad de indemnizaciones por el mismo daño, impidiendo la efectividad de uno y otro seguro (el de responsabilidad civil de vehículos de motor y el seguro obligatorio de viajeros), porque, de otro modo, se produciría una indeseable duplicidad indemnizatoria, con enriquecimiento indebido del perjudicado y menoscabo de elementales principios de justicia, coincidiendo tal previsión con el designio de la Ley cuando introdujo la dicha modificación y a lo que, en modo alguno, cabe oponer la declaración de compatibilidad contenida en los $\mathrm{n}^{\mathrm{o}} 2$ y 3 del artículo 2. ${ }^{\circ}$ del Reglamento del Seguro Obligatorio de Viajeros, dada la superior jerarquía de la Ley de Ordenación de Transportes, al punto (matiza la sentencia de la Sala 6. ${ }^{a}$ de esta Audiencia de 12-2-2007 (JUR 2007, 245084) que se habría producido una derogación tácita de los citados números del Reglamento de acuerdo con lo dispuesto en el artículo $2 .^{\circ} 2$ del $\mathrm{CC}$, todo ello en el bien entendido de que el tan dicho criterio reconoce a cada seguro distinto ámbito de actuación y, por tanto, declara su compatibilidad, pero no, se repite, el resultado indemnizatorio dual, resultante de la aplicación de uno y otro, cuando el riesgo resarcible sea el mismo.

Sin embargo, a juicio de esta Sala, las cosas no son tan así y es posible y parece más correcto otorgar a la modificación introducida otro propósito, en el sentido de que guarda relación y afecta al carácter obligatorio del seguro de viajeros contemplado en el $n^{\circ} 1$ del artículo 2. ${ }^{\circ}$ del Reglamento y no a la compatibilidad de otros seguros suscritos y las prestaciones satisfechas por otros responsables (números 2 y 3 del mismo artículo).

En efecto, lo que el artículo 21 de la LOTT regula y ordena es la suscripción de un seguro obligatorio en todo transporte público de viajeros que cubra los daños sufridos por éstos de acuerdo con los términos que establezca la regulación específica, que no es otra que el tan citado Reglamento del Seguro Obligatorio de Viajeros, obligación de suscripción que recuerda y recoge, de nuevo, el artículo 2.1 de éste y que la reforma estudiada, introducida en el artículo 21 de la LOTT, suaviza "en la medida" que los daños a que se refiere el Reglamento (art. 3. ${ }^{\circ}$ del mismo) ya estuvieren cubiertos y, por tanto, fuesen susceptibles de futuro resarcimiento a través del seguro de responsabilidad civil de vehículos, también de suscripción obligatoria.

Como bien se han cuidado de poner en evidencia las resoluciones del criterio mayoritario, el ámbito de cobertura de uno y otro seguro obligatorio no son en todo coincidentes y por eso que son efectivamente compatibles. A modo de ejemplo, baste decir que el Reglamento del Seguro Obligatorio de Viajeros limita su obligatoriedad a la cobertura de los daños corporales (art..$^{\circ}$ ), que no a las cosas, como, sin embargo sí 
obligatorio de viajeros no opera, por tanto, como mecanismo subsidiario para aquellos supuestos en que el evento no se halle cubierto por el sistema de responsabilidad civil del vehículo a motor y su seguro. Además, también hay que tener en cuenta que la indemnización derivada del seguro obligatorio de accidentes no está condicionada a la declaración o reconocimiento de responsabilidad por parte del porteador, ya que lo asegurado no es dicha responsabilidad sino el daño que sufre el viajero provisto del

ocurre con el Seguro de Responsabilidad Civil de Vehículos (art. 1. ${ }^{\circ}$ de esa Ley) o, más gráficamente, que el primero abarca el transporte marítimo (art. 4. ${ }^{\circ}-1-B$ ) o, incluso, al transporte en telesféricos, funiculares, telesquís, telesillas, telecabinas u otros medios (art. 10-C), lo que obviamente no ocurre con el Seguro de Vehículos, y de lo que resulta la compatibilidad de uno y otro a que se refiere el n ${ }^{\mathrm{o}} 2$ del artículo 2 . $^{\circ}$ o de las indemnizaciones que resulten del Seguro de Viajeros y de la responsabilidad dolosa o culposa atribuible al propio transportista o terceros, que regula el $\mathrm{n}^{\circ} 3$ del mismo articulado.

Por su parte, la compatibilidad de las indemnizaciones es posible cuando el transportista tanto haya suscrito el Seguro de Vehículos como otro de viajeros, porque uno y otro seguros no atienden al mismo riesgo ni al mismo interés y, además, el obligatorio de viajeros, en cuanto que calificado y concebido por el Reglamento como seguro de accidentes individual (art. 2. ${ }^{\circ}$ ) y, por tanto, como seguro de suma, no se halla sometido al principio de indemnización concreta y proscripción del enriquecimiento injusto proclamado en el artículo 26 de la LCS 50/1980, de 5 de octubre, de aplicación al seguro de daños (Título II) pero no al de personas (Título III).

El Seguro Obligatorio de Vehículos es un seguro de responsabilidad civil, es decir, de daños, en el que el riesgo asegurado es el derivado de la circulación de vehículos (art. 1. ${ }^{\circ}$ ), pero el interés protegido es el del responsable del daño, en cuanto que lo que se asegura no es la posibilidad del accidente de terceros sino la deuda de responsabilidad que se verá obligado a asumir el asegurado responsable, es decir y en suma, su patrimonio.

El seguro de accidentes, por el contrario, es un seguro de personas (Título III LCS), en el que el riesgo asegurado es el cuerpo humano (art. $80 \mathrm{LCS}$ ), y comprende todos aquéllos que pueden afectar a su existencia, integridad corporal o salud, correspondiendo el interés a la propia persona objeto del riesgo, de forma que la diferencia esencial con el seguro contra daños (entre los que está el de responsabilidad civil) estriba en que el daño, en aquél, no recae sobre cosas, sino sobre una persona, lo que hace difícil y delicada su estimación en dinero, de ahí su valoración anticipada por los contratantes al suscribir la póliza y su caracterización como "seguro de suma", es decir, aquél en que el asegurado no se compromete, estrictamente, a la indemnización del daño concreto sufrido, sino a la entrega de la suma convenida (art. $1 .^{\circ}$ LCS).

Expresamente el artículo 2. ${ }^{\circ}$ del Reglamento del SOVI califica de seguro privado de accidentes individuales el suscrito por el transportista (art. 22), regido lógicamente por él, pero también por la Ley de Contrato de Seguros 50/1980 de octubre ( $\mathrm{n}^{\circ} 4$ de ese artículo), en el que el tomador es el transportista (art. 5. ${ }^{\circ}$ ) pero el asegurado, el viajero (art. $6^{\circ}$ ), a quien se repercutiría el pago de la prima del seguro incorporándola al precio del transporte (art. 12.1.A).

Se trata, pues, de un seguro de accidentes propio e individual de cada viajero, del que éste se beneficia con la compra del billete, y en el que la suma asegurada viene fijada por Ley (art. 15.2 del Reglamento), y como seguro de tal clase no le es aplicable la prohibición del artículo 26 de la LCS ni el 32 (regulador del seguro múltiple), no sólo porque dicha normativa es sólo de aplicación al seguro de daños, sino por la muy cabal razón de que el valor del riesgo (el cuerpo humano) o del interés del asegurado en él (el propio titular de ese patrimonio físico) es inasequible a un valor concreto, cierto y unívoco como el de las cosas, más allá del cual pueda tacharse la pretensión de enriquecimiento injusto, por más que la Ley pueda, en los supuestos de contratación obligatoria y por razones de política legislativa, otorgarle uno concreto, de forma que, al fin y en consecuencia, no hay duplicidad en la indemnización sino distinto riesgo e interés resarcible, cabiendo llamar la atención sobre que el supuesto no se aleja de aquel otro habitual consecuente a accidente viario y consistente en que al lado de la indemnización por responsabilidad civil, puede ser que, por razón de la suscripción de una póliza de seguro de personas contratada por el propio perjudicado u otro, se haga éste acreedor, frente a su entidad aseguradora, de otra prestación económica que tenga como causa el estado físico resultante del siniestro viario»». 
correspondiente billete con ocasión del transporte ${ }^{46}$. En este seguro de accidentes, lo relevante es el daño independientemente de quien haya resultado culpable del siniestro ${ }^{47}$. Basta, por tanto, en el ámbito de este seguro, con que el viajero o sus causahabientes acrediten la causación de unas lesiones entre el momento en que el vehículo se pone a su disposición y hasta aquel en el que sale del mismo por el lugar debido (art. 8. ${ }^{\circ} 1 \mathrm{RD}$ 1575/1989) para tener derecho a la indemnización conforme al baremo que su propio reglamento establece. Y a la aseguradora corresponderá, si pretende exonerarse, acreditar la concurrencia de alguna circunstancia ajena, la ruptura del nexo de causalidad, o la actuación del viajero en forma dolosa o cuando se encuentre en estado de embriaguez o bajo los efectos de drogas, estupefacientes o estimulantes (art. 9. ${ }^{\circ}$ RD 1575/1989) ${ }^{48}$. A estos efectos, el concepto relevante de accidente no es el de accidente de circulación, sino el acuñado por el artículo 100 de la LCS, que entiende por accidente la lesión corporal que deriva de una causa violenta súbita, externa y ajena a la intencionalidad del asegurado, que produzca invalidez temporal o permanente o muerte.

En cuanto a la extensión temporal y espacial de la responsabilidad en el marco del Reglamento (UE) núm. 181/2011, hay que tener en cuenta que los viajeros tendrán derecho a una indemnización por los daños personales debidos a accidentes resultantes exclusivamente del uso del autobús o autocar, lo que deja fuera los accidentes ocurridos

\footnotetext{
${ }^{46}$ Cfr. REGLERO CAMPOS, F., op. cit., págs. 148 y 149.

47 En este sentido se pronuncia el Tribunal Supremo en sus Sentencias 618/2010, de 8 de octubre (TOL1.972.756) y 627/2011, de 19 de septiembre (TOL2.245.397). En particular, en la primera de ellas, recaída en un litigio en el que se debatió la cobertura por el seguro obligatorio de viajeros y el seguro obligatorio de la LRCSCVM de los daños y responsabilidad derivada del accidente sufrido por un pasajero que se cayó en el autobús en el que viajaba debido a un frenazo, el Alto Tribunal, acogiendo el criterio favorable a la compatibilidad de ambas indemnizaciones, declaró que la negativa de la AP a indemnizar con cargo al seguro obligatorio de viajeros por ausencia de culpa o responsabilidad del conductor del vehículo constituía una decisión errónea, toda vez que, a diferencia del seguro de responsabilidad civil, el seguro obligatorio de viajeros otorga a todo viajero que utilice un transporte público y en el momento del accidente esté provisto del título de transporte, el derecho a ser indemnizado «siempre que se produzca el hecho objetivo del accidente o daño, con independencia de la culpa o negligencia del conductor, empresario, o empleados, e incluso tercero, hasta el límite y en las condiciones establecidas en el mismo».
}

Como afirma LÓPEZ Y GARCÍA DE LA SERRANA, J., «Comentario a la Sentencia 27/2011, de 19 de septiembre», en https://www-tirantonlinecom.bibezproxy.uca.es/tol/documento/show/2245397?index=27\&searchtype=substring\&, «el Seguro Obligatorio de Viajeros, no tiene un sustrato culpabilístico, sino netamente objetivo; tiene su base en el mero hecho de utilizar un medio de locomoción destinado al transporte colectivo de personas, con independencia de la culpa o negligencia en que hayan podido incurrir la empresa de transportes o el conductor del vehículo o medio de transporte, pues los daños y perjuicios sufridos por el viajero derivados de esa culpa o imprudencia tienen otro régimen de indemnización, que es a su vez compatible con la cobertura objetiva que dispensa el Seguro Obligatorio de Viajeros, pero que no puede exigirse con cargo a este Seguro, sino, en su caso, con cargo al seguro de responsabilidad civil si lo hubiere, y, en todo caso, con cargo al patrimonio del autor de la conducta culpable o imprudente. Arts. 1902, 1911 Código Civil)».

${ }^{48}$ Sentencia de AP de Córdoba de 9 de mayo de 2000 (Sección 2. $)$ (AC 2000\1169). 
durante las estancias en las estaciones ${ }^{49} \mathrm{o}$ en las paradas ${ }^{50}$, los cuales quedan excluidos de la responsabilidad de los porteadores. En este sentido es notable la diferencia con el régimen previsto en el Reglamento (CE) núm. 1371/2007 para el transporte ferroviario, en donde la obligación de seguridad, y la consiguiente responsabilidad que pudiera derivarse de su incumplimiento, se extiende no sólo al periodo en el cual el viajero está dentro de vehículo ferroviario, sino también a la entrada y salida del mismo ${ }^{51}$, especificación ésta que no encontramos en el Reglamento (UE) núm. 181/2011, y que deja una puerta abierta a la litigiosidad.

Finalmente, en caso de accidente resultante del uso del autobús o autocar, el transportista proporcionará una asistencia adecuada y proporcionada a los viajeros para sus necesidades prácticas inmediatas tras el accidente. Esta asistencia incluirá, cuando resulte necesario, alojamiento, comida, ropa, transporte y prestación de primeros auxilios. La asistencia prestada no constituirá reconocimiento de responsabilidad.

\subsection{B.b. Daños a los equipajes y bultos de mano}

En cuanto al equipaje (cualquier objeto o conjunto de objetos que, a petición del viajero,

\footnotetext{
49 El Reglamento (UE) núm. 181/2011 entiende por estación la «dotada de personal donde, según la ruta determinada, está programada la parada de un servicio regular para el embarque o desembarque de viajeros, y equipada con instalaciones como las destinadas a la facturación, salas de espera o ventanillas para la venta de billetes».

${ }^{50}$ Por parada entiende el Reglamento (UE) núm. 181/2011 «cualquier punto, distinto de una estación, donde, según la ruta determinada, está programada la parada de un servicio regular para el embarque o desembarque de viajeros»».
}

51 Además, el artículo 26 del Reglamento (CE) núm. 1371/2007 recoge expresamente la obligación de seguridad personal de los viajeros, proyectándola no solo sobre el transportista sino también sobre todos aquéllos otros sujetos que intervienen en el transporte ferroviario (los administradores de infraestructuras y los administradores de estaciones). En efecto, para que la responsabilidad derivada de un accidente en el ámbito ferroviario se someta a las RU CIV (Reglas uniformes relativas al contrato de transporte internacional de viajeros y equipajes por ferrocarril, apéndice A COTIF, e incorporadas al citado Reglamento europeo) y genere, en principio, responsabilidad del transportista, éste ha de producirse durante la estancia del viajero en los coches ferroviarios, su entrada o salida de ellos, cualquiera que fuere la infraestructura ferroviaria utilizada (artículo 26.1 RU CIV). Cualquier otra eventualidad más allá de la entrada y salida de los vehículos ferroviarios podrá generar, en su caso, la responsabilidad de un administrador de infraestructuras o de estaciones, pero no del porteador en virtud del contrato de transporte. No obstante, el artículo 51 de las RU CIV, aplicando los principios de la llamada responsabilidad contractual indirecta, contempla la ficción legal de que los gestores de infraestructura ferroviaria en que se efectúe el transporte se consideran como personas a cuyo servicio recurre el transportista para la ejecución del transporte, precisando que el transportista será responsable de sus agentes y de las demás personas a cuyo servicio recurra para la ejecución del transporte, cuando dichos agentes o personas actúen en el ejercicio de sus funciones. Al declararse al administrador de infraestructuras auxiliar del transportista, se le aplica el artículo 52 RU CIV, en virtud del cual las reclamaciones contra los auxiliares del transportista, quedarán sujetas también a las condiciones y límites establecidos en las Reglas uniformes. Por tanto, el perjudicado podrá entablar acción de responsabilidad contractual contra el transportista o extracontractual, en su caso, contra el administrador de la infraestructura ferroviaria, beneficiándose en ambos casos de los privilegios probatorios que incorpora el sistema de responsabilidad previsto en las RU CIV y sometiéndose en contrapartida a las limitaciones de responsabilidad. En el supuesto en que sea el transportista el que asuma una indemnización por daños y perjuicios por causa de la infraestructura ferroviaria, podrá recuperarlas vía de regreso contra el administrador de la misma [cfr. ROMERO MATUTE, B., «Régimen jurídico privado del contrato de transporte de viajeros por ferrocarril», Revista de derecho del transporte núm. 18 (2016), págs. 11 a 62]. 
acompañan a éste durante el viaje a bordo de la bodega, la baca o el remolque del mismo vehículo) parece que deberían aplicarse analógicamente las reglas propias del transporte de cosas. En consecuencia, el porteador, en virtud del contrato de transporte, respondería por los daños, pérdidas y averías que sufran los equipajes de los viajeros de la misma manera (supuestos, causas de exoneración, daños indemnizables...) en que responde, con carácter general, el transportista de mercancías. No obstante, el transporte de equipajes no es propiamente un transporte de mercancías a los efectos de la LCTTM, sino una prestación complementaria que se encuadra en el marco de un transporte de personas. Por ello, se aplica su normativa específica; de esta forma, y en lo que concierne a la limitación de la responsabilidad del porteador, se habrá de estar:

a) Dentro de su ámbito de aplicación (transportes en autobús o autocar con embarque o desembarque dentro de la Unión Europea, tanto discrecionales como los regulares cuya distancia programada sea igual o superior a $250 \mathrm{~km}$ ), al Reglamento (UE) núm. 181/2011, según el cual los viajeros, de conformidad con el Derecho nacional vigente, tendrán derecho a una indemnización por la pérdida o daño del equipaje, cuando tales daños sean consecuencia de accidentes resultantes del uso del autobús o autocar. El importe de la indemnización se calculará de conformidad con el Derecho nacional vigente, teniendo en cuenta que el límite máximo establecido por el Derecho nacional a la indemnización por la pérdida o daño del equipaje para cada ocasión no será inferior a 1.200 euros por pieza de equipaje (art. 7. ${ }^{\circ}$ ). Este mismo límite se recoge en el artículo 23.1 LOTT, tras su redacción por la Ley 9/2013, dejando abierta la posibilidad de que expresamente se pacten unas cuantías o condiciones más favorables para el viajero.

b) Con respecto a los transportes por carretera que queden fuera del ámbito de aplicación del mencionado Reglamento (UE) núm. 181/2011, debe considerarse lo dispuesto en el artículo 23 LOTT — tras su redacción por la Ley 9/2013 - que establece que la responsabilidad por los daños o pérdidas que sufran los equipajes estará limitada, salvo que expresamente se pacten unas cuantías o condiciones más favorables para el viajero, a 450 euros por pieza.

En relación con los bultos de mano (pequeños objetos destinados al abrigo, adorno o uso personal que un viajero lleve consigo durante el viaje a bordo del habitáculo del vehículo), señala el artículo 23 LOTT que su vigilancia corresponderá al viajero al que acompañan $\mathrm{y}$, en consecuencia, serán de su cuenta los daños que aquéllos puedan sufrir mientras se encuentren a bordo del vehículo, salvo que pruebe la responsabilidad del porteador, en cuyo caso serán de aplicación las limitaciones antes mencionadas en relación con el equipaje (art. 23 LOTT). En todo caso, se considerará responsable al transportista de la posible pérdida o deterioro de los bultos de mano ocurrida en algún momento en el que, con ocasión de una parada, todos los ocupantes hubieran abandonado el vehículo sin que inmediatamente después, el conductor hubiera cerrado las puertas de acceso al mismo.

Por el contrario, a diferencia de los equipajes y bultos de mano, sí se contemplen expresamente en la LCTTM los llamados «encargos» (objetos que el transportista se obliga a conducir por cuenta ajena a bordo del vehículo cuando dichos objetos no guarden 
relación directa con ninguno de los viajeros que ocupe plaza en el vehículo). En efecto, según la disposición adicional segunda, se aplicará al transporte de los «encargos»el régimen de la propia LCTTM. Y ello resulta probablemente lógico, por cuanto lo más adecuado es considerar que el transporte de «encargos» constituye un verdadero transporte de mercancías concertado con un porteador (principalmente) de viajeros. En este caso, producido el incumplimiento, el porteador no habrá de indemnizar la totalidad de los daños producidos sino que su responsabilidad se halla cuantitativamente limitada (art. 57 LCTTM): a) en los supuestos de pérdidas o averías de la mercancía, el límite máximo de la indemnización a satisfacer por el porteador viene representado por $1 / 3 \mathrm{del}$ Indicador Público de renta de Efectos Múltiples/día por cada kilogramo de peso bruto de mercancía perdida o dañada; b) en los supuestos de retraso, la indemnización que el porteador deberá abonar al destinatario no podrá exceder del precio del transporte. Cuando como consecuencia del retraso se produzca la pérdida o avería de los géneros, la indemnización a satisfacer no podrá exceder de la prevista para el caso de pérdida total. Ahora bien, el porteador no podrá hacer uso del beneficio de la limitación de responsabilidad, cuando de conformidad con lo previsto en el artículo 62 LCTTM, el incumplimiento se hubiera producido de forma dolosa o gravemente culposa.

\subsection{B.c. Cancelación, interrupción, retraso en la salida}

La responsabilidad del porteador por retraso en el transporte o la falta de ejecución total o parcial del mismo no es objeto de regulación en el ámbito del transporte de viajeros (a diferencia de su tratamiento por la LCTTM respecto al transporte de mercancías), debiendo suplirse la laguna legal con la legislación civil específica del contrato de obra y la general sobre el incumplimiento de los contratos (arts. 1.101 y ss. del Código civil). No obstante, en lo que se refiere a los transportes regulares por autobús y autocar cuyo punto de embarque o desembarque esté situado en la Unión Europea y cuya distancia programada sea igual o superior a $250 \mathrm{~km}$ (se excluye de este régimen a los transportes discrecionales), hay que atender a lo dispuesto en el Reglamento (UE) núm. 181/2011, artículos 19 a 23. Esta norma incrementa notablemente las obligaciones de información de modo accesible para estos supuestos y, sin perjuicio de cualquier otra reclamación que corresponda al viajero de conformidad con su Derecho nacional, se establece que cuando un transportista tenga razones para suponer que un servicio regular va a cancelarse o a tener un retraso significativo (cifrado en más de ciento veinte minutos) en su salida desde una estación, o efectivamente se cancele o se retrase más de ciento veinte minutos, así como en caso de sobrerreserva, debe ofrecer de inmediato al viajero (con billete cerrado o abierto que especifique hora de salida o con pase de temporada) la posibilidad de elegir entre: a) Continuación o recorrido alternativo hasta el destino final sin coste adicional y en la primera ocasión posible, en condiciones comparables a las estipuladas en el contrato de transporte; b) reembolso del precio del billete $\mathrm{y}$, si procede, un servicio de vuelta gratuito en autobús o autocar en la primera ocasión posible, al primer punto de partida mencionado en el contrato de transporte. Se exceptúan los casos en los que el transportista demuestre que la cancelación o el retraso se debe a condiciones meteorológicas extremas o a grandes catástrofes naturales que hacen peligrosa la seguridad del servicio de autobús 
o autocar. La falta de ofrecimiento al viajero para que elija entre las opciones expuestas se penaliza con una indemnización que ascenderá al 50 por 100 del precio del billete, además del reembolso del precio del billete. En su caso, el pago del reembolso se habrá de efectuar en efectivo, a no ser que el viajero acepte otra forma de pago, en los 14 días siguientes al ofrecimiento o a la recepción de la solicitud. El pago cubrirá el coste total del billete, al precio que se haya pagado, de la parte o partes del viaje que no se hayan hecho y de la parte o partes ya realizadas si el viaje no sirve ya a los fines del plan de viaje original del viajero. Para los viajeros que estén en posesión de pases de viaje o de abonos de temporada, el pago será equivalente a la parte proporcional del coste completo del pase o abono.

En caso de avería del autobús o autocar durante el viaje, el transportista facilitará bien la continuación del servicio con otro vehículo desde el punto en que se encuentre el vehículo averiado, o bien transporte desde el punto en que se encuentre el vehículo averiado hasta un punto de espera o una estación adecuados desde donde sea posible la continuación del viaje.

Además, para los viajes de duración superior a tres horas, se prevé una obligación de asistencia al viajero en caso de cancelación o retraso en la salida de más de noventa minutos, que consistirá en el ofrecimiento de comidas o refrigerios en proporción razonable al retraso, siempre que puedan razonablemente proveerse; alojamiento, y traslados al mismo, pudiendo limitar el transportista a 80 euros por noche y por viajero, por un máximo de dos noches, el coste total del alojamiento. En caso de que los transportistas incumplan su obligación de prestar a los viajeros la asistencia necesaria, éstos tienen derecho a una compensación económica.

\subsection{B.d. Cuestiones procesales}

En el ámbito nacional, en esta materia hay que destacar el posible sometimiento automático a arbitraje recogido en el artículo 38.1 de la LOTT, tras su modificación por la Ley 9/2013. Así, dispone que corresponde a las Juntas Arbitrales resolver, con los efectos previstos en la legislación general de arbitraje, las controversias de carácter mercantil surgidas en relación con el cumplimiento de los contratos de transporte terrestre cuando, de común acuerdo, sean sometidas a su conocimiento por las partes intervinientes $\mathrm{u}$ otras personas que ostenten un interés legítimo en su cumplimiento, presumiendo que existe el referido acuerdo de sometimiento al arbitraje de las Juntas siempre que la cuantía de la controversia no exceda de 15.000 euros y ninguna de las partes intervinientes en el contrato hubiera manifestado expresamente a la otra su voluntad en contra antes del momento en que se inició o debiera haberse iniciado la realización del transporte o actividad contratados $^{52}$. Por otro lado, el artículo 14 TRLSCSVM prevé la posibilidad de

\footnotetext{
52 Al respecto, Vid. SÁNCHEZ GAMBORINO, F.M., «Juntas Arbitrales de Transporte. Actividades de mediación», en AA.VV., Manual de Derecho del transporte, dir. por MARTÍNEZ SANZ, F., Marcial Pons, Madrid, 2010, págs. 249 a 266; RODRIGUEZ SÁNCHEZ, S., Las juntas arbitrales de transporte: constitución y funciones, Tirant lo Blanch, Valencia, 2010; SÁNCHEZ GONZÁLEZ, F., «Las Juntas Arbitrales del transporte», Actualidad jurídica del transporte por carretera: In memoriam F.M. Sánchez
} 
sometimiento de las controversias relacionadas con la responsabilidad civil en el ámbito de la circulación al procedimiento de mediación previsto en la Ley 5/2012, de 6 de julio, de mediación en asuntos civiles y mercantiles. En caso de no sometimiento a arbitraje o mediación, la competencia corresponde a los juzgados de lo mercantil, en virtud de lo previsto en el artículo 86 ter Ley Orgánica 6/1985, de 1 de julio, del Poder Judicial, que les atribuye el conocimiento de las cuestiones del orden jurisdiccional civil, respecto de las pretensiones que se promuevan al amparo de la normativa en materia de transportes, nacional o internacional.

Respecto a la prescripción de las acciones de reclamación de la responsabilidad derivada de daños a las personas o a sus equipajes, hay que estar al régimen general de prescripción previsto en el Código Civil: un año para la responsabilidad extracontractual (art. 1.968.2 ${ }^{\circ}$ ) y cinco para la responsabilidad por incumplimiento contractual, plazo que debe de computarse desde la fecha en que pueda exigirse el cumplimiento de la obligación (art. 1.964).

Para determinar la competencia judicial en los supuestos de transporte transfronterizo o con elementos de extranjería, hay que estar a lo preceptuado en el Reglamento (UE) núm. 1215/2012 del Parlamento Europeo y del Consejo de 12 de diciembre de 2012, relativo a la competencia judicial, el reconocimiento y la ejecución de resoluciones judiciales en materia civil y mercantil (RBI bis). Descartada la aplicación para los contratos de transporte de los foros de competencia judicial internacional de protección, relativos a la competencia en materia de contratos celebrados por los consumidores (art. 17.3 Reglamento núm. 1215/2012), ante una controversia en materia de transporte internacional de viajeros por carretera, siempre y cuando se cumplan los requisitos de aplicación del RBI bis, salvo pacto en contrario, el demandante podrá interponer acción ante el tribunal del lugar del Estado miembro en el que, según el contrato, hayan o deban ser prestados los servicios de transporte (art. 7. ${ }^{\circ} .1 . b$ Reglamento núm. 1215/2012). Es decir, el demandante podrá elegir interponer la acción ante el lugar de origen o el lugar de destino del transporte internacional de viajeros por carretera o en el lugar del domicilio

Gamborino, 2005, págs. 93 a 104; GUILLÉN CARAMÉS, J., «El arbitraje de consumo como mecanismo de protección de los usuarios de transportes terrestres», en AA.VV., Derecho público del transporte en la ciudad: renovación y nuevas perspectivas de la movilidad urbana, dir. CARBONELL PORRAS, E. CANO CAMPOS, T., Universidad Complutense de Madrid, Facultad de Derecho, Madrid, 2009, págs. 99 a 130; GUILLÉN CARAMÉS, J., «Los derechos de los usuarios de transportes terrestres por carretera y ferrocarril», op. cit., págs. 54 a 57 y 92 a 104; ESTANCONA PÉREZ, A.A., op. cit., págs. 100 a 108 ; CASCALES MORENO, F.J., «Arbitraje y conciliación en el transporte terrestre: las Juntas de Detasas, las Juntas de Conciliación e Información del Transporte Terrestre y las Juntas Arbitrales del Transporte», $L a$ Ley. Mediación y arbitraje, . $^{\circ} 1$ (Enero-Marzo), 2020; CARBONELL PORRAS, E. - VÁZQUEZ RUANO, T. - MARTÍNEZ GUTIÉRREZ, A., «La resolución extrajudicial de conflictos en el transporte: las Juntas Arbitrales de Transporte», en AA.VV., El transporte como motor del desarrollo socioeconómico, dir. por PETIT LAVALL, M.V. - PUETZ, A., Marcial Pons, Madrid, 2018, págs. 49 a 66; BADA DE COMINGES, M., «Las juntas arbitrales de transporte», en AA.VV., Régimen jurídico del transporte terrestre: carreteras y ferrocarril, op. cit., págs. 985 a 1006; GUEDEA MARTÍN, M., «Los arbitrajes especiales en nuestro ordenamiento jurídica: estudio específico de la Ley de Ordenación de los Transportes Terrestres», en AA.VV., El derecho de los transportes terrestres, coord. por BERMEJO VERA, J., 1999, págs. 211 a 238; GUTIÉRREZ SANZ, M. ${ }^{a}$ R., «Transporte terrestre de viajeros y resolución extrajudicial de conflictos», en AA.VV., El contrato de transporte de viajeros, nuevas perspectivas, op. cit., págs. 175 a 226. 
del demandado (arts. 4. ${ }^{\circ} .1$ y 5. ${ }^{\circ} .1$ Reglamento núm. 1215/2012).

En cuanto a la ley aplicable, y al margen de la invocación específica por el Reglamento (UE) núm. 181/2011 de los derechos nacionales de los viajeros para determinar los quantums indemnizatorios en distintos supuestos de responsabilidad del porteador, hay que distinguir entre el transporte internacional y el de cabotaje. Respecto al contrato de transporte internacional de pasajeros, dispone específicamente el artículo $5 .^{\circ} .2$ Reglamento (CE) núm. 593/2008 del Parlamento Europeo y del Consejo, de 17 de junio de 2008, sobre la ley aplicable a las obligaciones contractuales (Roma I), que, en defecto de elección por las partes de la ley aplicable ${ }^{53}$, el contrato se regirá por la ley del país donde el viajero tenga su residencia habitual, siempre y cuando el lugar de origen o el lugar de destino también estén situados en ese país. Si no se cumplen estos requisitos, se aplicará la ley del país donde el transportista tenga su residencia habitual. Sin embargo, para el transporte de cabotaje hay que tener en cuenta lo dispuesto en el artículo 16 Reglamento (CE) núm. 1073/2009, que reclama como normas aplicables al transporte de cabotaje las disposiciones legales, reglamentarias y administrativas vigentes en el Estado miembro de acogida, en lo que se refiere a las condiciones que rigen el contrato de transporte, entre otros ámbitos ${ }^{54}$.

\section{BIBLIOGRAFÍA}

AA.VV., Comentario a la Ley de Transporte Terrestre, dir. por DUQUE DOMÍNGUEZ, J. --MARTÍNEZ SANZ, F., y c168urope por EMPARANZA SOBEJANO, A PETIT LAVALL, M. ${ }^{\mathrm{a}}$ V., Aranzadi Thomson Reuters, Cizur Menor, 2010.

AA.VV., Comentario del Texto Refundido de la Ley General para la Defensa de los Consumidores y Usuarios y otras leyes complementarias (Real Decreto Legislativo 1/2007), c168urope por BERCOVITZ RODRÍGUEZ-CANO, R. Aranzadi Thomson Reuters , 2. ${ }^{a}$ ed., Cizur Menor, 2015.

\footnotetext{
${ }^{53}$ No obstante, existen igualmente restricciones relativas a los puntos de conexión que deben de respetar las partes en su elección de la ley aplicable al contrato de transporte de viajeros por carretera. En efecto, el artículo 5.2, párrafo segundo, del Reglamento Roma I, únicamente permite a las partes elegir como ley aplicable alguna de las siguientes: a) la ley del país donde el pasajero tenga su residencia habitual; b) la ley del país donde el transportista tenga su residencia habitual; c) la ley del país donde el transportista tenga el lugar de su administración central; d) la ley del país donde se encuentre el lugar de origen; y, e) la ley del país donde se encuentre el lugar de destino. Como destaca la doctrina, dichos puntos de conexión son los más habituales para su elección por las partes de la relación contractual; vid., al respecto, LLORENTE GÓMEZ DE SEGURA, C., "La ley aplicable al contrato de transporte internacional según el Reglamento Roma I", Cuadernos de Derecho Transnacional, 2009, vol.1, núm. 2, págs. 171 a 178.

${ }^{54}$ Para mayor amplitud, BELINTXON MARTIN, U., «Derecho Internacional Privado y transporte de viajeros por carretera: algunas cuestiones sobre jurisdicción y ley aplicable», Cuadernos de Derecho Transnacional, Vol. 8, núm. 1 (2016), págs. 25 a 35; BELINTXON MARTIN, U., «La calificación del transporte de cabotaje como transporte internacional en el Derecho del transporte por carretera: el elemento de la internacionalidad», Revista de Derecho del Transporte, núm. 16 (2015), págs. 141 a 166.
} 
AA.VV., El contrato de transporte de viajeros, nuevas perspectivas, dir. por ZUBIRI SALINAS, M., Aranzadi Thomson Reuters, Pamplona, 2016.

AA.VV., La nueva ordenación del mercado de transporte, dir. por RECALDE CASTELLS, A.- MARTÍNEZ SANZ, F. --PETIT LAVALL, M. ${ }^{a}$ V., coord. por PUETZ, A, Marcial Pons, Madrid, 2013.

AA.VV., La Responsabilidad Civil por Daños Causados por Servicios Defectuosos. Estudio de la responsabilidad civil por servicios susceptibles de provocar daños a la salud y seguridad de las personas, dir. por ORTI VALLEJO A. --GARCÍA GARNICA, M.C., coord. por ROJO ÁLVAREZ-MANZANEDA, R., Aranzadi Thomson Reuters, Pamplona, 2015.

AA.VV., Régimen Jurídico del Transporte Terrestre: Carreteras y Ferrocarril, dir. por MENÉNDEZ GARCÍA, P., T. II, Aranzadi Thomson Reuters, Navarra, 2014.

AAVV, Manual de Derecho del Transporte, dir. por MARTÍNEZ SANZ, F. y coord. por PUETZ, A., Marcial Pons, Barcelona, 2010.

AGOUÉS MENDIZABAL, C., «La intervención administrativa en el transporte de viajeros por carretera», Revista del Derecho del Transporte núm. 7 (2015), págs. 74 a 82.

ARIAS VARONA, F.J., «El comportamiento subjetivo del porteador como causa de la pérdida de los beneficios de la limitación de responsabilidad», Revista de Derecho del Transporte, núm. 6 (2010), págs. 283 a 302.

BADA DE COMINGES, M., «Las juntas arbitrales de transporte», en AA.VV., Régimen jurídico del transporte terrestre: carreteras y ferrocarril , dir. por MENÉNDEZ GARCÍA, P., T. II, Aranzadi Thomson Reuters, Navarra, 2014, págs. 985 a 1006.

BADILLO ARIAS, J.A., La conceptualización del hecho de la circulación en la responsabilidad civil automovilística y el seguro, Getafe, 2015, tesis doctoral en abierto en https:/earchivo.uc3m.es/bitstream/handle/10016/21597/Jose_Bardillo_tesis.pdf?sequenc $\mathrm{e}=1$ \&isAllowed $=\mathrm{y}$.

BELINTXON MARTIN, U., «Derecho internacional privado y transporte de viajeros por carretera: algunas cuestiones sobre jurisdicción y ley aplicable», Cuadernos de Derecho Transnacional (Marzo 2016), Vol. 8, núm. 1, págs. 17 a 35.

BELINTXON MARTIN, U., «La calificación del transporte de cabotaje como transporte internacional en el Derecho del transporte por carretera: el elemento de la internacionalidad», Revista de Derecho del Transporte, núm. 16 (2015), págs. 141 a 166. 
BLANCO PÉREZ-RUBIO, L. «Obligaciones de medios y obligaciones de resultado: ¿tiene relevancia jurídica su distinción?», Cuadernos de Derecho Transnacional, Vol. 6, núm. 2, 2014, págs. 50 a 74.

BLANQUER CRIADO, D.V., «El transporte de viajeros por carretera: servicio económico de interés general y libertad de empresa; las obligaciones de servicio público», en AA.VV., Régimen jurídico del transporte terrestre: carreteras y ferrocarril, dir. por MENÉNDEZ GARCÍA, P., T. I, Aranzadi Thomson Reuters, Pamplona, 2014, págs. 691 a 750.

CABANILLAS SÁNCHEZ, A., Las obligaciones de actividad y de resultado, Barcelona, 1993.

CARBONELL PORRAS, E. --VÁZQUEZ RUANO, T. --MARTÍNEZ GUTIÉRREZ, A., «La resolución extrajudicial de conflictos en el transporte: las Juntas Arbitrales de Transporte», en AA.VV., El transporte como motor del desarrollo socioeconómico, dir. por PETIT LAVALL, M.V. - PUETZ, A., Marcial Pons, Madrid, 2018, págs. 49 a 66.

CARBONELL PORRAS, E., Régimen jurídico-administrativo del transporte interurbano por carretera, Madrid, 1993.

CASCALES MORENO, F.J., «Arbitraje y conciliación en el transporte terrestre: las Juntas de Detasas, las Juntas de Conciliación e Información del Transporte Terrestre y las Juntas Arbitrales del Transporte», La Ley. Mediación y arbitraje, n. ${ }^{\circ} 1$ (enero-marzo) 2020.

CONTRERAS DELGADO DE COS, J. M. --SILOS RIBAS, M. --SOBRINO RUIZ, M., "Capítulo duodécimo. La economía colaborativa en los sectores regulados (III). Transporte de viajeros", en AA.VV., Retos jurídicos de la economía colaborativa en el contexto digital, dir. por ALFONSO SÁNCHEZ, R. --VALERO TORRIJOS, J. Cizur Menor, 2017, págs. 309 a 335.

DÍAZ MORENO, A., «El contrato de transporte terrestre nacional de mercancías», en AA.VV., Derecho mercantil, Vol. $8^{\circ}$ (Transportes mercantiles), coord. por JIMÉNEZ SÁNCHEZ, G. --DÍAZ MORENO, A., Marcial Pons, Madrid, 2014, págs. 245 y ss.

DÍEZ-PICAZO, L., Derecho de daños, Civitas, Madrid, 1999, págs. 366 y 367.

ESTANCONA PÉREZ, A.A., Transporte Terrestre de pasajeros. Contratación, responsabilidad y seguro, Tirant lo Blanch, Valencia 2018.

FINCK, M. (2018). «Distinguishing internet platforms from transport services: Elite Taxi v. Uber Spain», Common Market Law Review, Vol. 55, núm. 5, págs. 1619 a 1640. 
GABALDÓN GARCÍA, J.L., «Intermediarios del transporte y porteadores contractuales», Revista de Derecho Mercantil, núm. 238, 2000, págs. 1723 a 1747.

GABALDÓN GARCÍA, J.L., El concepto de porteador en el transporte de mercancías, Granada, 2003.

GARCÍA ÁlVAREZ, B., «Los Derechos de los Viajeros en la Unión Europea: A propósito de la Comunicación de la Comisión al Parlamento Europeo y al Consejo de 19 de diciembre de 2011», Cuadernos de Derecho Transnacional (Octubre 2012), Vol. 4, núm. 2, págs. 284 a 299.

GARCÍA-RIPOLL MONTIJANO, M., «El hecho de la circulación en la responsabilidad civil automovilística», en AA.VV., Cuestiones clásicas y actuales del Derecho de daños: Estudios en Homenaje al Profesor Dr. Roca Guillamón, coord. por ATAZ LÓPEZ, J. --COBACHO GÓMEZ, J.A., Aranzadi Thomson Reuters, Vol. 2, 2021, págs. 873 a 968.

GLEAVE, S.D., Evaluation of Regulation 1371/2007. Final Report, European Commission DG MOVE, 2012.

GORRIZ LÓPEZ, C., "Taxi vs Uber: De la competencia desleal al arrendamiento de vehículo con conductor”, Revista de Derecho mercantil, núm. 311, 2019, págs. 241 y ss.

GORRIZ LÓPEZ, C., «Uber. Transporte de pasajeros y competencia desleal», Revista de Derecho del Transporte, núm.16 (2015), págs. 77 a 98.

GORRIZ LÓPEZ, C., La responsabilidad en el contrato de transporte de mercancías (carretera, ferrocarril, marítimo, aéreo y multimodal), Publicaciones del Real Colegio de España, Bolonia, 2001.

GUEDEA MARTÍN, M., «Los arbitrajes especiales en nuestro ordenamiento jurídico: estudio específico de la Ley de Ordenación de los Transportes Terrestres», en AA.VV., El derecho de los transportes terrestres, coord. por BERMEJO VERA, J., 1999, págs. 211 a 238.

GUILLÉN CARAMÉS, J., «Los derechos de los usuarios de transportes terrestres por carretera y ferrocarril», en AA.VV., Régimen jurídico del transporte terrestre: carreteras y ferrocarril, T. II, dir. por MENÉNDEZ GARCÍA, P., Aranzadi Thomson Reuters, Navarra, 2014, págs. 38 a 42.

GUILLÉN CARAMÉS, J., «El arbitraje de consumo como mecanismo de protección de los usuarios de transportes terrestres», en AA.VV., Derecho público del transporte en la ciudad: renovación y nuevas perspectivas de la movilidad urbana, dir. CARBONELL PORRAS, E. --CANO CAMPOS, T., Universidad Complutense de Madrid, Facultad de Derecho, Madrid, 2009, págs. 99 a 130. 
GUILLÉN NAVARRO, N.A., «El arrendamiento de vehículos con conductor (VTC) y su entramado jurídico: el avance de Uber, Cabify y la economía colaborativa», Revista de Estudios de la Administración Local y Autonómica. Nueva Época, núm. 9, 2018, págs. 128 a 147.

GULlÓN, A., Curso de Derecho civil. El negocio jurídico, Madrid, 1969.

GUTIÉRREZ SANZ, M. ${ }^{a}$ R., «Transporte terrestre de viajeros y resolución extrajudicial de conflictos», en AA.VV., El contrato de transporte de viajeros, nuevas perspectivas, dir. por ZUBIRI SALINAS, M., Aranzadi Thomson Reuters, Pamplona, 2016, págs. 175 a 226.

HERNÁNDEZ BAREA, H., «Concurrencia de culpas: moderación de indemnizaciones», Cuadernos de derecho judicial, Ejemplar dedicado a Derecho de seguros, III, dir. por ARROYO FIESTAS, F.J., núm. 12, 1997, págs. 109 a 238.

HERNÁNDEZ CUETO, C., «El uso de baremos en la valoración de daños personales. La reforma del baremo de tráfico», Cuadernos médicos forense, Vol. 20, núm. 4, 2014, http://scielo.isciii.es/scielo.php?script=sci_arttext\&pid=S113576062014000300001 .

HOLGADO, J., «El nuevo baremo les vuelve locos», Capital Madrid, 15 de julio de 2014, https://www.capitalmadrid.com/2014/7/15/34532/el-nuevo-baremo-les-vuelvelocos.html;

HUALDE MANSO, $\mathrm{M}^{\mathrm{a}}$ T., El transporte de viajeros por carretera: régimen de responsabilidad civil, Aranzadi Thomson Reuters, Pamplona, 1996.

Informe «Observatorio del transporte de viajeros por carretera. Contratos de Gestión de la Administración General del Estado (noviembre 2020)» en https://www.mitma.gob.es/recursos_mfom/comodin/recursos/observatorio_2019 .pdf .

Informe «Observatorio del transporte de viajeros por carretera. Oferta y demanda (enero 2021)»

https://www.mitma.gob.es/recursos_mfom/comodin/recursos/observatorio_viaje ros_-_oferta_y_demanda_enero_2021.pdf

JIMÉNEZ HORWITZ, M., «Los riesgos a cargo del perjudicado», en AA.VV., La Responsabilidad Civil por Daños Causados por Servicios Defectuosos. Estudio de la responsabilidad civil por servicios susceptibles de provocar daños a la salud y seguridad de las personas, dir. por ORTI VALLEJO A. --GARCÍA GARNICA, M.C., coord. por ROJO ÁlVAREZ-MANZANEDA, R., Aranzadi Thomson Reuters, Pamplona, 2015, págs. 131 a 177. 
JORDANO FRAGA, J. «Obligaciones de medios y de resultado (A propósito de alguna jurisprudencia reciente)», Anuario de Derecho Civil, 1991, págs. 7 y ss.

LACRUZ BERDEJO, J.L., Elementos de Derecho Civil, T. II, Vol. 1. ${ }^{\circ}$, Barcelona, 1985.

LLORENTE GÓMEZ DE SEGURA, C., "La ley aplicable al contrato de transporte internacional según el Reglamento Roma I", Cuadernos de Derecho Transnacional, 2009, Vol.1, núm. 2, págs. 171 a 178.

LLORENTE GÓMEZ DE SEGURA, C., «La responsabilidad en el transporte de personas y de mercancías», en AA.VV., Practicum daños 2015, coord. por SOLER PRESAS, A. -DEL OLMO GARCÍA, P., Pamplona, 2014, págs. 591 y ss.

LOBATO GÓMEZ, J.M., «Contribución al estudio de la distinción entre obligaciones de medios y obligaciones de resultado», Anuario de Derecho Civil, 1992, págs. 651 y ss.

LÓPEZ GARCÍA DE LA SERRANA, J., "La consideración jurídica del servicio prestado por la plataforma Uber a la luz de la Jurisprudencia del TJUE", en AA.VV., Propuestas de regulación de las plataformas de economía colaborativa: Perspectivas general y sectoriales, dir. por RUBIO GIMENO, G. --ORTÍ VALLEJO, A., Aranzadi, Navarra, 2019, págs. 325 y ss.

LÓPEZ ORTEGA, R., «Las plataformas Uber, BlaBlaCar y Airbnb ¿Intermediarias o prestadoras del servicio subyacente?», Revista de Derecho Mercantil, núm. 321, 2021.

LÓPEZ QUIROGA, J., «Transporte de viajeros por carretera», en AAVV, Manual de Derecho del Transporte, dir. por MARTÍNEZ SANZ, F. y coord. por PUETZ, A., MARCIAL Pons, Barcelona, 2010, págs. 419 y ss.

LÓPEZ Y GARCÍA DE LA SERRANA, J., «Comentario a la Sentencia 27/2011, de 19 de septiembre», en https:/www-tirantonlinecom.bibezproxy.uca.es/tol/documento/show/2245397?index $=27 \&$ searchtype $=$ su bstring\&.

MAGRO SERVET, V., «Moderación de la indemnización en accidentes de tráfico por concurrencia de la culpa de la víctima o perjudicado», Tráfico y seguridad vial, núm. 89, 2006, págs. 5 a 14.

MAMBRILLA RIVERA, V., «La política europea de transportes (Hacia el establecimiento de un "Espacio Único Europeo del Transporte)», Revista de Derecho del Transporte, núm. 9 (2012), págs. 37 a 84.

MAMBRILLA RIVERA, V., «La protección de los derechos de los pasajeros en la Unión Europea», en AA.VV., La nueva ordenación del mercado de transporte, dir. por 
RECALDE CASTELLS, A.- MARTÍNEZ SANZ, F. -PETIT LAVALL, M. ${ }^{a}{ }^{\text {V., }}$ coord. por PUETZ, A, Marcial Pons, Madrid, 2013, págs. 887 a 910.

MARTÍN-CASALS M., «A través del espejo: concurrencia de "“ulpa"”de la víctima y culpa del causante del daño», en AA.VV., Estudios jurídicos en homenaje al profesor Luis Díez-Picazo, coord. por CABANILLAS SÁNCHEZ, A., Vol. 2. ${ }^{\circ}$, Civitas, Madrid, 2002, págs. 2471 a 2490.

MEDINA CRESPO, M., El resarcimiento de los perjuicios personales causados por la muerte en el nuevo Baremo de Tráfico, Bosch, Madrid, 2015.

MENÉNDEZ, A, «El contrato de pasaje marítimo», en AA.VV., Centenario de la Ley de Notariado, Vol. 4, Madrid, 1963, pág. 286.

MONTERROSO CASADO, E., Responsabilidad por Accidentes de Circulación. La Concurrencia de Causas, Aranzadi, Navarra, 2009.

MONTÉS PENADÉS, V.L., «Casualidad, imputación objetiva y culpa en la "“oncurrencia de culpas"”, en AA.VV., Estudios jurídicos en homenaje al profesor Luis Díez-Picazo, coord. por CABANILLAS SÁNCHEZ, A., Vol. 2, Civitas, Madrid, 2002, págs. 2591 a 2628.

OLMEDO PERALTA, E., Régimen jurídico del transporte marítimo de pasajeros. Contratos de pasaje y crucero, Marcial Pons, Madrid, 2014.

PACHECO CAÑETE, M., «Cuestiones de actualidad sobre la responsabilidad del transportista marítimo por daños a los pasajeros», Revista de Derecho del Transporte, núm. 9. ${ }^{\circ}$ (2012), págs. 97 y 98.

PARRA LUCÁN, M. ", "Daños causados por otros bienes o servicios", en AA.VV., Comentario del Texto Refundido de la Ley General para la Defensa de los Consumidores y Usuarios y otras leyes complementarias (Real Decreto Legislativo 1/2007), ), coord. por BERCOVITZ RODRÍGUEZ-CANO, R.

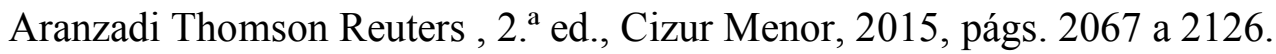

PARRA LUCÁN, M., "Responsabilidad civil por bienes o servicios defectuosos", en AA.VV., Comentario del Texto Refundido de la Ley General para la Defensa de los Consumidores y Usuarios y otras leyes complementarias (Real Decreto Legislativo 1/2007), coord. por BERCOVITZ RODRÍGUEZ-CANO, R. Aranzadi Thomson Reuters , 2. ${ }^{a}$ ed., Cizur Menor, 2015, págs. 1843 a 1928.

PARRA LUCÁN, M. ${ }^{a}$, «Responsabilidad civil por bienes y servicios en el Texto Refundido de la Ley general de la defensa de los consumidores y usuarios», en Práctica derecho daños: Revista de Responsabilidad Civil y Seguros, núm. 69, 2009, págs. 5 a 23. 
PASQUAU LIAÑO, M., «El defecto de seguridad como criterio de imputación de responsabilidad al empresario de servicios», en AA.VV., La Responsabilidad Civil por Daños Causados por Servicios Defectuosos. Estudio de la responsabilidad civil por servicios susceptibles de provocar daños a la salud y seguridad de las personas, dir. por ORTI VALLEJO A. --GARCÍA GARNICA, M.C., coord. por ROJO ÁlVAREZ-MANZANEDA, R., Aranzadi Thomson Reuters, Pamplona, 2015, págs. 59 a 102.

PAZOS CASTRO, R., «Uber, Airbnb y la llamada "influencia decisiva” de las plataformas digitales», Revista de Internet, Derecho y Política, núm. 31, 2020, págs. 1 a 14.

PEINADO, J.I., «El Contrato de Transporte Terrestre (I). El transporte de mercancías y viajeros por carretera», en AA.VV., Lecciones de Derecho Mercantil, dir. por MENÉNDEZ, A. - ROJO, A., Civitas, Pamplona, 2019, pág. 172.

PILOÑETA ALONSO, L. M., «El contrato de transporte terrestre de personas: Fundamentos de su régimen jurídico, elementos y contenido», en AA.VV., Régimen Jurídico del Transporte Terrestre: Carreteras y Ferrocarril, T. II, dir. por MENÉNDEZ GARCÍA, P., T. II, Aranzadi Thomson Reuters, Navarra, 2014, págs. 855 a 871 .

PILOÑETA ALONSO, L. M., «El subtransporte: análisis crítico y teórico de un concepto práctico», Revista de Derecho Mercantil, núm. 262, 2006, págs. 1401 a 1438.

PULIDO BEGINES, J.L., «El concepto de porteador y la dualidad porteador contractualporteador sustituto en las CIM-1999», Revista de Derecho Mercantil, núms. 264265, 2007, págs. 533 a 598.

PULIDO BEGINES, J.L., El concepto de porteador efectivo en el Derecho uniforme del transporte, Marcial Pons, Madrid, 2012.

QUINTANA CARLO, I., «Hacia una regulación unitaria del transporte de personas», en AA.VV., El contrato de transporte de viajeros, nuevas perspectivas, dir. por ZUBIRI SALINAS, M., Aranzadi Thomson Reuters, Pamplona, 2016, págs. 21 a 45.

QUINTANA CARLO, I., «La regulación del transporte terrestre de viajeros y la desidia del legislador español», Revista del Derecho del Transporte núm. 16 (2015), págs. 11 a 29.

RAMOS HERRANZ, I., «El estándar mercantil de diligencia: El ordenado empresario», Anuario de Derecho Civil, núm. LIX-1, Enero 2006, págs. 195 a 225.

RAZQUIN LIZARRAGA, J.A., Derecho público del transporte por carretera, Aranzadi Thomson Reuters, Pamplona 1995. 
REGLERO CAMPOS, F., «Los seguros de responsabilidad civil y accidentes», en AA.VV., La Responsabilidad Civil por Daños Causados por Servicios Defectuosos. Estudio de la responsabilidad civil por servicios susceptibles de provocar daños a la salud y seguridad de las personas, dir. por ORTI VALLEJO A. --GARCÍA GARNICA, M.C., coord. por ROJO ÁLVAREZ-MANZANEDA, R., Aranzadi Thomson Reuters, Pamplona, 2015, págs. 146 a 166.

REGLERO CAMPOS, L.F. - PEÑA LÓPEZ, F., , «El nexo causal. La pérdida de oportunidad. Las causas de exoneración de responsabilidad: culpa de la víctima y fuerza mayor», en AA.VV., Tratado de responsabilidad civil, coord. por REGLERO CAMPOS, L.F.- BUSTO LAGO, J.M., Aranzadi Thomson Reuters, Pamplona, 2014, págs. 767 a 970.

RODRÍGUEZ MARÍN, S. «Aspectos jurídicos de la economía colaborativa y bajo demanda en plataformas digitales», en AA.VV., Aspectos legales de la economía colaborativa y bajo demanda en plataformas digitales, coord. por RODRÍGUEZ MARÍN, S. --MUÑOZ GARCÍA, A., Bosch, Las Rozas (Madrid), 2018, págs. 43 a 76.

RODRIGUEZ SÁNCHEZ, S., Las juntas arbitrales de transporte: constitución y funciones, Tirant lo Blanch, Valencia, 2010.

ROJO ÁLVAREZ-MANZANEDA, C., «La indemnización al viajero por causa de los daños personales en los servicios de transporte por carretera y ferrocarril», Revista Aranzadi de derecho patrimonial, núm. 35, 2014, págs. 239 a 273.

ROJO ÁLVAREZ-MANZANEDA, C., «La institución del seguro como sistema de protección al viajero por los daños personales causados en el contrato de transporte por carretera», en AA.VV., La nueva ordenación del mercado de transporte, , dir. por RECALDE CASTELLS, A.- MARTÍNEZ SANZ, F. -PETIT LAVALL, M. ${ }^{a}$ V., coord. por PUETZ, A, Marcial Pons, Madrid, 2013, págs. 777 a 781 .

ROJO ÁLVAREZ-MANZANEDA, C., «La responsabilidad civil por servicios de transporte terrestre que afectan a la seguridad de las personas», Revista de Derecho Mercantil, núm. 259, 2006, págs. 55 a 114.

ROJO ÁLVAREZ-MANZANEDA, C., «Responsabilidad civil por daños personales a los viajeros en los servicios de transporte por carretera», Diario La Ley, núm. 7825, 2012.

ROJO ÁlVAREZ-MANZANEDA, C., «Transporte Terrestre», en AA.VV., La Responsabilidad Civil por Daños Causados por Servicios Defectuosos. Estudio de la responsabilidad civil por servicios susceptibles de provocar daños a la salud y seguridad de las personas, dir. por ORTI VALLEJO A. --GARCÍA GARNICA, 
M.C., coord. por ROJO ÁlVAREZ-MANZANEDA, R., Aranzadi Thomson Reuters, Pamplona, 2015, págs. 383 a 399.

ROMERO COLOMA, A.M., «Accidentes de tráfico: los supuestos de culpa exclusiva de la víctima, caso fortuito y fuerza mayor», Revista de Responsabilidad Civil, Circulación y Seguro, núm. 10, 1998, págs. 528 a 533.

ROMERO MATUTE, B., «Régimen jurídico privado del contrato de transporte de viajeros por ferrocarril», Revista de derecho del transporte, núm. 18 (2016), págs. 11 a 62.

ROZO SORDINI, P.E, «Las obligaciones de medios y de resultado y la responsabilidad de los médicos y los abogados en el derecho italiano», Revista de Derecho Privado, núm. 4, 1999, págs. 139 a 142.

RUDA GONZÁLEZ, A. «Responsabilidad por hechos ajenos en la economía colaborativa. El caso de UBER», en AA.VV., Collaborative Economy. Challenges \& Opportunities, coord. por BALCELLS, J., Huygens Editorial Barcelona, 2018, págs. 424 a 440.

SÁNCHEZ CALERO GUILARTE, J. --SÁNCHEZ CALERO, F., Instituciones de Derecho Mercantil, Vol. II, Aranzadi Thomson Reuters, Pamplona, 2015.

SÁNCHEZ GAMBORINO, F.M., «Juntas Arbitrales de Transporte. Actividades de mediación», en AA.VV., Manual de Derecho del transporte, dir. por MARTÍNEZ SANZ, F., Marcial Pons, Madrid, 2010, pág. 249 a 266.

SÁNCHEZ GONZÁLEZ, F., «Las Juntas Arbitrales del transporte», Actualidad jurídica del transporte por carretera: In memoriam F.M. Sánchez Gamborino, 2005, págs. 93 a 104.

SOTO NIETO, F., «La llamada compensación de culpas», Revista de Derecho Privado, núm. 52, 1968, págs. 409 a 427.

TOURIÑO, A., «Régimen de responsabilidad de las plataformas que operan en el ámbito de la economía colaborativa», en AA.VV., Aspectos legales de la economía colaborativa y bajo demanda en plataformas digitales, coord. por RODRÍGUEZ MARÍN, S. --MUÑOZ GARCÍA, A., Bosch, Las Rozas (Madrid), 2018, págs. 77 a 101.

TULLIO, L, «La obligación de protección en el transporte marítimo y aéreo», Revista de Derecho del Transporte, núm. 11 (2013), págs. 11 a 27.

URÍA, R., Derecho mercantil, Marcial Pons, Madrid, 2001. 
VALCÁRCEL FERNÁNDEZ, P., "Transporte terrestre de mercancías y viajeros por carretera”, en AA.VV., Derecho de la Regulación Económica: VI. Transportes, $1^{a}$ edición, Madrid, Iustel, 2009, págs. 81 y ss.

VALCÁRCEL FERNÁNDEZ, P., «Régimen jurídico del transporte terrestre de mercancías y viajeros por carretera», en AA.VV., Derecho de la regulación económica, dir. por MUÑOZ MACHADO, S., Vol. 6, 2010 (Transportes), págs. 11 a 308.

ZUBIRI DE SALINAS, M., «La responsabilidad del transportista de personas en los Reglamentos Comunitarios relativos al transporte aéreo, ferroviario y marítimo», Revista del Derecho del Transporte, núm. 4 (2010), págs. 67 a 100. 